\title{
How Do Adolescents SPELL TIME USE?
}

\author{
Charlene M. Kalenkoski \\ Department of Economics, Ohio University \\ Bentley Annex 351, Athens, Ohio 45701 USA \\ 740-593-2022 (phone) • 740-593-0181 (fax) \\ e-mail: kalenkos@ohio.edu \\ David C. Ribar ${ }^{*}$ \\ Department of Economics, University of North Carolina at Greensboro \\ P.O. Box 26165, Greensboro, North Carolina 27402-6165 USA \\ 336-334-3904 (phone) • 336-334-4089 (fax) \\ e-mail: dcribar@uncg.edu \\ Leslie S. Stratton* \\ Department of Economics, Virginia Commonwealth University \\ 301 W. Main Street, Richmond, Virginia 23284-4000 USA \\ 804-828-7141 (phone) • 804-828-1719 (fax) \\ e-mail: 1sstratt@vcu.edu
}

August 2009

JEL Codes: J22 ,J13

Keywords: Time use, adolescence, event history models

\begin{abstract}
:
We investigate how household disadvantage affects the time use of 15-18 year-olds using 20032006 data from the American Time Use Survey. Applying competing-risk hazard models, we distinguish between the incidence and duration of activities and incorporate the daily time constraint. We find that teens living in disadvantaged households spend less time in nonclassroom schooling activities than other teens. Girls spend some of this time in work activities, suggesting they are taking on adult roles. However we find more evidence of substitution into unsupervised activities, suggesting that it may be less structured environments that reduce educational investment.

*Research Fellows at IZA, Bonn, Germany

Acknowledgements: Leslie S. Stratton is the corresponding author. The authors thank Deborah Cobb-Clark, Nancy Folbre, Daniel Hamermesh, Robert Pollak, Jay Stewart and participants at numerous workshops and conferences for insightful comments.
\end{abstract}




\section{Introduction}

Adolescence is an important stage in a child's development. Neither completely dependent nor wholly independent, adolescents occupy a middle ground in modern societies. It is during these years that individuals make significant investments in education, begin to shoulder responsibilities in the world of work, and are granted greater autonomy - behaviors that will have substantial long run consequences. Not surprisingly, research on adolescents has historically concentrated on academic achievement and transitions into adult roles. Of particular concern is how disadvantage, as measured by family structure, work environment, and parental education, impact such outcomes.

Most studies of youths' schooling have focused on outcomes such as test scores or highest grade completed. There has been much less research on the daily processes that give rise to these outcomes. However, given the availability of time-diary data, researchers have begun to examine the day-to-day activities of teenagers in more detail. In this study, we use time diaries collected from 2003-2006 by the American Time Use Survey (ATUS) to study the time that teens devote each day to schooling and other activities.

Empirical studies of teens' (and others') time use have been hampered by several significant limitations. First, many of the analyses have used aggregate measures of time use, such as daily minutes spent in a particular activity. Use of such aggregate measures, however, fails to utilize the detail available in time-diary data, which provide information on what activities are being performed and with whom every minute of the day. In contrast to this approach, we examine the activities as spells and estimate competing-risk hazard models of teenagers' continuation in and transitions out of these activities. A hazard approach is consistent with the way that the data are reported. The methodology also allows us to account for time-of- 
day effects, heaped reporting times, and other features of the data that aggregate studies necessarily overlook.

Second, a central research question regarding time use is how time devoted to one activity might crowd out time devoted to other activities. Thus, if disadvantaged teens are spending less time in schooling, research should address what they are doing instead. One possibility is that disadvantaged teens are devoting more time to housework or market labor. Another is that these teens take advantage of less supervision and pursue less structured schedules. Previous research has considered competing activities only in a limited way. Our methodology enforces an overall time constraint that allows us to see the tradeoffs teenagers make.

Third, many previous studies have used single-index specifications, such as linear regressions or Tobit models. These studies have not been able to distinguish between the incidence and duration of activities. Our approach, which considers transitions between different activities, incorporates this distinction in a natural way.

We estimate models that distinguish among six mutually exclusive uses of teenagers' time: class time, other schooling activities (e.g. homework and extracurricular activities, except sports), market and household work, sleep, and supervised and unsupervised other activities. We disaggregate classroom time and other schooling because class time is not truly discretionary. The models include parents' living and work arrangements, parents' education, numbers of other children, local labor market conditions, and other characteristics as explanatory variables.

Estimation reveals that teens living in single-parent households and boys living with two working parents spend less time in non-classroom schooling activities than similar teens living in other households. Teens living with less educated parents also spend less time in non-classroom 
schooling activities. Although we find evidence that some types of disadvantage cause girls to work more, it appears that much of the reduction in non-classroom schooling time is accompanied by an increase in unsupervised other activities. There is also evidence of later waking times for some teens. Overall, the results strongly suggest that disadvantaged teens' diminished school performance may be due to lack of supervision and structure.

\section{Literature Review}

It is well-established that children who grow up in disadvantaged circumstances tend to obtain less schooling and perform worse on cognitive tests than other children. ${ }^{1}$ Such diminished educational attainment can lead to fewer skills, lower earnings, and other negative outcomes later in life. Yet, how does disadvantage translate into poorer schooling outcomes? One hypothesis is that living in disadvantaged circumstances forces children to shoulder increased responsibility and take on adult roles earlier than other children.

For example, families with single parents or working mothers may lack the time resources of other families, necessitating more housework by adolescents. Numerous researchers, including Peters and Haldeman (1987), Goldscheider and Waite (1991), Hilton and Haldeman (1991), Demo and Acock (1993), Gager et al. (1999), and Capizzano et al. (2004), have found that teenagers, especially girls, living in single-parent households spend more time in housework (including child care) than those in dual-parent households. Call et al. (1995) reported greater housework among teens with working mothers. However, Goldscheider and Waite (1991) found little evidence that maternal employment had much of an effect on the extent to which children took responsibility for household tasks.

\footnotetext{
${ }^{1}$ There is an extensive literature on adolescent attainments. Reviews are available in Haveman and Wolfe (1994), Duncan and Brooks-Gunn (1997), and Bowles et al. (2005).
} 
Greater household need in the form of a larger household or more young siblings may also increase the demands on teenagers' time. In their review of the consequences of welfare-towork programs on adolescents' development, Gennetian et al. (2002) found that adolescent children of welfare recipients who had younger siblings experienced larger negative effects on school performance, and were more likely to be suspended or expelled from and to drop out of school, than adolescent children of welfare recipients who were not subject to such policies. Call et al. (1995) reported that household size was an important predictor of the time teenagers spent in housework and caring activities.

Teens may also assume adult roles through paid employment. Such employment may increase skills through experience. At the same time, it may be detrimental to school performance. Oettinger (1999), for example, found a decline in the grades of minority high school students who work long hours. Similarly, Tyler (2003) found that employment while in high school has a negative effect on $12^{\text {th }}$ grade math achievement, and Kalenkoski and Pabilonia (2009a, 2009b) found that the employment of high school students reduces time spent on homework. Kalenkoski and Pabilonia (2009b) also found that such employment reduces the time teens spend sleeping, which may negatively affect the efficacy of time spent in educational investment due to fatigue. Not all studies find negative effects of student employment, however (see, for example, Ruhm 1995, 1997; Leventhal et al. 2001; and Rothstein 2007). Furstenberg (2000) reviews additional research on the benefits and consequences of youth employment. Zick (2007) examined changes in adolescents' work and other activities over time. She found that recent cohorts of teens spend substantially less time in paid employment than teens in the 1970s. However, the time freed from working has not led to more time in school or other enriching activities. Instead, time spent in passive leisure activities has increased. 
Zick's research suggests another way that disadvantage may translate into poorer schooling outcomes - through inadequate parental supervision. Increased autonomy, independence, and disengagement are part of the process of growing up. Nevertheless, some teens may be given too much autonomy and provided with too little supervision too soon. Using time-diary data on teenagers' activities from the ATUS, Price et al. (2007) found that teenagers with a single parent go to bed later and are less likely to eat dinner with a parent. They also found that teens with more educated parents spend more time studying and less time watching $\mathrm{TV}$, are more likely to eat dinner with a parent, and get less sleep. An increase in work among disadvantaged teens, which Price et al. also found, might increase their independence and disrupt parents' ability to supervise their teens. However, in a study limited to two-parent families, Bryant and Zick (1996) found that maternal employment led to a shift in the type of activities parents shared with children but not in the amount of time shared.

Other studies have also investigated the relationship between family circumstances and teenagers' activities using time diary data. While Porterfield and Winkler (2007) found that teen time use differs relatively little across different types of families, they found that such time use does vary markedly by race, ethnicity, and parental education, which may also proxy for disadvantaged circumstances. For example, they found that parental education is positively associated with teenagers' homework time. Marshall (2007) found that family environment is a strong predictor of time spent in homework by Canadian teens, with teens more likely to do homework and more of it if both parents had a university education, and if they lived in a twoparent, intact family. She also found that teens with demanding paid jobs did significantly less homework than those who were not employed. Kalenkoski and Pabilonia (2009b) found that having an employed mother increases a teen's probability of employment, having more educated 
parents positively affects homework time, having a more-educated mother negatively affects screen time, and living with a single parent reduces homework time.

While the above-mentioned time-diary studies have tried to determine how teenagers' daily activities are affected by family circumstances, these studies suffer from several limitations. First, they rely on analyses of total daily time spent in various activities but do not separately account for the incidence and duration of activities. Second, they do not account for the timing and interdependence of different activities. Third, they do not account for the daily time constraint that requires that additional time spent in one activity must reduce time spent in at least one other activity. Our event-history approach addresses all of these issues.

\section{Data and Methodology}

We conduct our empirical analyses of teenagers' time allocations using individual-level time-diary data from the 2003-2006 ATUS. The ATUS is a national survey that has been conducted regularly since January 2003 by the U.S. Bureau of the Census for the U.S. Bureau of Labor Statistics. The study first randomly selects households in their last month of participation in the Current Population Survey (CPS). It then selects one person aged 15 or over within each household to participate in a phone interview during which the subject provides a 24-hour time diary and answers other questions. Because the ATUS uses the CPS as a sampling frame, it has a stratified design. In addition, the diaries in the ATUS oversample weekend days. We use survey-provided sampling weights to make the ATUS representative of the national population and of an average day.

The distinctive feature of the ATUS is that it collects a retrospective, one-day diary, describing how the respondent spent his or her time. Subjects report the activities they were 
performing throughout the day in their own words. They also report when these activities began and ended, where the activities occurred, and who else was present. The Census Bureau subsequently codes the responses into standardized activities in an episode format. These episodes are the source material for the activities that we examine.

A critical feature of the ATUS for our purposes is that it supports multivariate analyses of teenagers' behavior. The survey randomly selects one person aged 15 years or older from the sampled households and does not restrict the sample to household heads or spouses. Although teenagers constitute a small proportion of the ATUS study population, there are ample observations to study because the survey itself is large and because cross-sections can be pooled over time (there were approximately 20,000 respondents in 2003 and 13,000 respondents in each of the subsequent years). Our analyses focus on 15-18 year-olds who live with at least one parent, do not live with children of their own, have not completed a high school degree or equivalent, and who provided at least 23 hours of diary information. We further restrict the analysis sample to teenagers who reported being enrolled in school and who provided diary information during a school week. ${ }^{2}$ The restrictions on enrollment, grade completion, and school-week reports are intended to reduce the sample heterogeneity, to abstract from drop-out and school-continuation decisions, and to support analyses of schooling-related activities. The restrictions on living arrangements were also made to reduce heterogeneity; however, they additionally allow us to focus on dependent adolescents and to characterize the parents' circumstances. Taken together, the restrictions produce an analysis sample that is somewhat more advantaged than teenagers generally.

Activity spell data. We group the detailed activities reported in the ATUS into six broad

\footnotetext{
${ }^{2}$ We defined school weeks as the weeks between the Labor Day and Memorial Day holidays, excluding the nine days from Christmas Eve to New Years Day.
} 
categories. The first two categories comprise school-related activities. Here we differentiate between classroom time, over which individuals have relatively little choice, and homework and other school-related activities (not including school sports), over which individuals have more discretion. A third category contains market and household work activities, including care for household children and grocery shopping. A fourth category contains sleep- or rest-related activities. The remainder of a teen's time is divided into two "other" categories. These distinguish between activities in which a parent or other adult is present (supervised other activities) and not present (unsupervised other activities). We then concatenate all consecutive spells for a teenager that are of the same broad type; for instance, a spell of doing the laundry followed by a spell of vacuuming is treated as a single spell of work. Collapsing the activities this way reduces the number of spells by about half.

Next we take steps to simplify our subsequent event history analyses and reduce the number of minor transitions that we need to consider. In particular, we restrict the sample to include only teenagers who were sleeping at or within 10 minutes of $4 \mathrm{a} . \mathrm{m}$. on the initial day of the diary. Thus, we only have to consider a single origin type of activity—sleep. This restriction reduces the sample by 62 teenagers. From our concatenated spells, we then drop 919 activity spells that were reported to have lasted 5 minutes or less (a reduction of 4.4 percent of the available concatenated activities and 0.1 percent of the total time reported in the diaries). We next concatenate "new" sleep spells that began before 6:30 a.m. and that were preceded by single, short, non-sleep activities with earlier sleep spells, dropping the intervening activities and treating the initial and subsequent periods of sleep as continuous spells. For example, a teen who woke up, drank a glass of water, and then went back to sleep would have both sleep spells counted as one continuous sleep spell and the time spent drinking water would 
be ignored. Similarly, we concatenate non-retiring sleep spells that began after 12:30 a.m. with the retiring sleep spells. These changes only affect 5 spells. We then recode all of the remaining (342) non-initial and non-terminal sleep spells (naps) as "unsupervised other" activities.

Although we would have liked to examine these sleep spells as such, there were simply too few of them to model separately.

Explanatory measures. In addition to the activity data, the ATUS asks each subject to identify who else lives in the household and to list each member's gender, age, and relationship to the subject. We use these rosters to construct household composition measures. Adolescents who report having only one parent present at the time of the time diary and adolescents whose parent indicates being unmarried are coded as living in a single-parent household. ${ }^{3}$ Other conditioning variables include indicators for whether the parents in the household worked; the highest level of education attained by the parents; the number of other adults and the number of other adolescents in the household; the number of younger children in different age ranges in the household; indicator variables for the race/ethnicity and age of the teen and themetropolitan status of the household; and the state unemployment rate. In our analysis we also condition upon whether the diary day fell on a weekend or holiday. We drop 35 observations that are missing information on one or more of the covariates.

Characteristics of the analysis sample. Our final analysis sample has information on 9,861 concatenated activity spells for 1,004 teenage girls and 8,963 spells for 1,005 teenage boys. All of the teenagers report at least two activity spells, and the median number of spells is nine. Characteristics of the teenagers in our analysis, including the total minutes and daily incidence of activities, household circumstances, and personal attributes, are shown in Table 1.

\footnotetext{
${ }^{3}$ We code married couples who are living apart as single-parent households because the household time constraints more nearly resemble those of single-parent households.
} 
The distributions of activities across non-holiday weekdays and across weekend days and holidays are shown in Figure 1 separately for teenage girls and boys. Figure 1 plainly shows that activities are unevenly distributed across the hours of each day and across different types of days, mostly in ways that we would anticipate. For example, almost all classroom activities occur between 7 a.m. and 3 p.m. on weekdays. Sleep is concentrated early and late in the day, with teenagers rising earlier on weekdays. Work is more likely to occur on weekend days or holidays than on weekdays. To the extent that work does take place on weekdays, it tends to occur in the afternoon and early evening. Finally, the graphs show that when teenagers are not attending school, supervised and unsupervised other activities dominate their waking hours. Teenage boys are more likely to be involved in unsupervised other activities than teenage girls, especially outside of regular school hours.

For our event history analyses, each time diary is divided into 144 10-minute intervals. To conduct the hazard analysis, we identify for each interval whether the activity continued or whether a transition to a different activity occurred. The transition patterns based on these data are shown in Table 2. ${ }^{4}$ As we would expect given the large number of intervals and the modest number of spells during the day, the vast majority of the interval-to-interval observations are continuations of activities. When we do look at the actual changes in activities we see that most of these involve transitions into or out of the supervised and unsupervised other activities. There are relatively few transitions among the remaining activities.

\section{Econometric Model}

We model the transitions among the broad groups of activities defined in the previous

\footnotetext{
${ }^{4}$ Although the ATUS diary format is very flexible and allows individuals to report spells of any length, most of the activities were reported to end at times consistent with 10 -minute intervals. Thus, the time intervals are essentially reported in discrete intervals.
} 
section using discrete-time, competing-risk hazard methods. Let $j$ and $k$ be index variables that denote different activities $(=0$ if morning sleep, $=1$ if classroom schooling activities, $=2$ if other schooling activities, = 3 if work, = 4 if "other" supervised activities, $=5$ if "other" unsupervised activities, and $=6$ if retiring sleep). Let $h_{j k}$ be the hazard of transitioning from activity $j$ to activity $k$. As we mentioned, morning sleep $(j=0)$ is the origin activity for everyone in the analysis sample. If $j$ equals 0 , the teenager's “choice set," $M_{0}$, is to continue sleeping or to transition to any of the other activities except retiring sleep $\left(M_{0}=\{0,5\}\right)$. Once the teenager has woken up and transitioned to one of the other activities (1-5), he or she can continue in that activity or transition to any of the other activities except for morning sleep $\left(M_{j}=\{1,6\}\right.$ for $j$ in $\{1,5\})$. Retiring sleep is modeled as a terminal activity; once a teenager has transitioned into retiring sleep, he or she is assumed to remain in that activity $\left(M_{6}=\{6\}\right)$. This gives rise to 6 types of spells and 36 types of transitions that can be modeled. ${ }^{5}$ All of the activity spells except morning and retiring sleep can be repeated.

We adopt the discrete-time, competing risk hazard framework described by Allison (1982) and model each transition as a function of the duration of the spell $(d)$, the time of day $(t)$, family structure and economic circumstances $(F)$, and other observed covariates $(X)$, using a multinomial logit specification

$$
h_{j, k}(d, t)=\frac{\exp \left(\alpha_{j k} A_{d}+\beta_{j k} B_{t}+\gamma_{j k} F+\delta_{j k} X\right)}{\sum_{m \in M_{j}} \exp \left(\alpha_{j m} A_{d}+\beta_{j m} B_{t}+\gamma_{j m} F+\delta_{j m} X\right)}
$$

where $A_{d}$ is a vector of duration controls for the spell, $B_{t}$ is a vector of time-of-day and cumulative activity duration controls, and $\alpha_{j k}, \beta_{j k}, \gamma_{j k}$, and $\delta_{j k}$ are vectors of coefficients to be

\footnotetext{
${ }^{5}$ There is a $37^{\text {th }}$ transition (from one period of retiring sleep to another) that does not need to be modeled.
} 
estimated. ${ }^{6}$ The specification is a type of proportional hazards model in which the term $\alpha_{j k} A_{d}$ accounts for the baseline duration dependence pattern and the other terms shift this pattern up or down. In estimating the model, the coefficients associated with continuation in a given activity $-\alpha_{j j}, \beta_{j j}, \gamma_{j j}$, and $\delta_{j j}$-are normalized to zero.

As we saw in Table 2, there are numerous transitions into and out of the supervised and unsupervised other activities but relatively few transitions directly between the remaining activities. The "thin" transitions (e.g., $1 \rightarrow 2,1 \rightarrow 3,1 \rightarrow 6,2 \rightarrow 1$ ) do not have enough observations to support estimating all of the coefficients in specification 1. For these transitions, we instead estimate a restricted specification, consisting of an intercept and an indicator for whether the activity took place on a weekend or holiday.

As a sensitivity test, we also estimate models that include a common unobserved variable or factor, $\eta$, to control for the possibility of spurious duration dependence within spells and for potential associations in behavior across spells that may arise from unmeasured, person-specific characteristics. These models take the form

$$
h_{j, k}(d, t)=\frac{\exp \left(\alpha_{j k} A_{d}+\beta_{j k} B_{t}+\gamma_{j k} F+\delta_{j k} X+\lambda_{j k} \eta\right)}{\sum_{m \in M_{j}} \exp \left(\alpha_{j m} A_{d}+\beta_{j m} B_{t}+\gamma_{j m} F+\delta_{j m} X+\lambda_{j m} \eta\right)}
$$

where $\lambda_{j k}$ is an additional coefficient. For the distribution of the unobserved factor, we adopt a semi-parametric, discrete distribution following the approach of Heckman and Singer (1984). These distributions include two points of support, and the locations and probabilities of these points are estimated using the aML software package (Lillard and Panis 2003).

Although our event-history approach is more complicated than the OLS and Tobit approaches usually employed to examine daily time-use data, we see several crucial advantages

\footnotetext{
${ }^{6}$ To reduce the amount of notation, we omit subscripts identifying the teenager and the spell.
} 
to this technique. Most importantly, our approach conforms to the underlying structure of the data and the reporting process for activities in the ATUS. Event history models are a natural way to model the duration of spells and hence activities, but they also respect other features of the data. In particular, they allow us to model entry into different activities, thus letting us examine and distinguish between characteristics that contribute to the incidence of an activity and the duration of the activity. This is an improvement over single-index OLS and Tobit specifications. The models also fully account for the fact that the uses of time are reported as mutually exclusive events. In previous research, the restrictions associated with mutual exclusivity and the daily time constraint for multiple activities have only been addressed informally, such as through seemingly unrelated regression specifications (e.g., Kalenkoski et al. 2005, 2007). Through the spell duration, cumulative duration, schedule, and finite-mixture heterogeneity controls, the models account for the distributions of activity times in a comprehensive and logically consistent way. We avoid the distributional problems inherent in standard Tobit models and can apply the methods in circumstances where other less restrictive approaches, such as Censored Least Absolute Deviations (CLAD), cannot be applied. ${ }^{7}$ Nevertheless, the methods still address the same underlying censoring issue. Finally, the methods address other relevant features of time use data, such as time-of-day effects and heaped reporting times, that studies have typically either overlooked or addressed in relatively ad hoc ways (e.g., Brayfield 1995, Hamermesh 2005, Presser $1986,1988,1994) .^{8}$

General specification issues. Our event history models incorporate parametric controls for current spell duration and time-of-day effects. While the controls we adopt are relatively flexible, some initial specification decisions are still required. After an examination of the spell

\footnotetext{
${ }^{7}$ The CLAD procedure can only be applied if the incidence of an activity is more than 50 percent.

${ }^{8}$ An exception is Hamermesh's (1999) study, which comprehensively examined work probabilities at every hour of the day.
} 
distributions and some initial testing, we adopted piecewise linear specifications (linear splines) for the current spell duration dependence patterns, with the segments connecting at two-hour intervals during a spell up to the eighth hour. Unlike a series of dummy-variable (step-function) controls, the piecewise linear specifications avoid discrete jumps at the connecting points of the baseline hazard function. That said, descriptive analyses did reveal that all of the hazards exhibited spikes at regular 30- and 60-minute intervals - these occur because people tend to report activities in half-hour and hour increments. To account for this reporting behavior, all of our models include dummy controls for spell intervals that end in a 30 - or 60 -minute increment. While the locations of the connecting segments and the dummy controls are fixed, the other shape parameters - the slopes along the piecewise linear functions and the levels of the spikes associated with the dummy controls — are all estimated and therefore determined by the data.

Our model also allows for separate time-of-day effects depending on whether the activity occurred on a weekday or on a weekend or holiday. For each type of day and for most of our activities, we specify piecewise linear functions that are constrained to be flat from 4 a.m. to 7 a.m., to have a two-hour segment running to 9 a.m., and to have three-hour segments thereafter through either 9 p.m. or 12 a.m., depending on the activity. The transition to nighttime sleep is specified differently with a long flat segment running through 6 p.m. and two three-hour spline segments thereafter. In each of the models, the flat segments early and late in the day correspond to times when there were very few transitions. These restrictions are needed to avoid conditioning (near-complete sample separation) problems in the models at thin points in the time-of-day distributions. Again, the slopes of the other segments of the piecewise linear functions are estimated.

In addition to these controls, all of our models, except the hazard function for morning 
sleep, incorporate measures for the cumulative amounts of time spent in sleep, classroom activities, other schooling activities, work, and other supervised time from 4 a.m. till the present time. These cumulative duration effects are identified separately from the within-spell duration effects by times spent in previous spells.

\section{Results}

As the description of the econometric specifications indicates, we jointly estimate numerous transitions among daily activities, utilizing a broad array of control variables. We have organized the results tables for our primary specification first by gender and then by the type of transition. Tables $3 a$ and $3 b$ list selected coefficient estimates and estimated standard errors from the models for teenage girls, and Tables $4 \mathrm{a}$ and $4 \mathrm{~b}$ list the results for boys.

The first two columns in Tables $3 \mathrm{a}$ and $4 \mathrm{a}$ contain coefficients corresponding to the transitions from initial morning sleep into supervised other activities and unsupervised other activities. The coefficients for the remaining three "thin" transitions into classroom, other schooling, and work activities are omitted from the tables but available upon request (recall that the coefficients for these transitions are limited to an intercept and an indicator for weekends or holidays). The next two columns in Tables $3 \mathrm{a}$ and $4 \mathrm{a}$ list coefficients corresponding to the transitions from classroom activities into supervised and unsupervised other activities. The next two columns contain coefficients for the transitions from other schooling activities into supervised and unsupervised other activities. The final two columns contain coefficients corresponding to the transitions from work into supervised and unsupervised other activities.

In Tables $3 b$ and $4 b$, the first five columns contain coefficients corresponding to the transitions from supervised other activities into each of the possible remaining activities, while 
the final five columns list coefficients for the transitions from unsupervised other activities into the remaining activities. All of the estimates come from multinomial discrete-time transition models in which the omitted transition categories are continuation in the original activities.

The estimated coefficients and standard errors for specific control variables are listed by row in the tables. The first three rows in each table list the coefficients for the parents' living arrangements and work status. The estimates from Table $3 \mathrm{a}$ indicate that living in a household in which both parents work or in which the father does not work (as opposed to a "traditional" twoparent household where only the father works) reduces the risk of girls transitioning from classroom activities to supervised other activities. Living with a non-working father also reduces the risks of girls leaving other schooling activities for supervised other activities. According to Table 3b, parents' work status is not strongly associated with girls' exits from supervised other activities, so the net effect of having two working parents or a non-working father on the total time spent in supervised other activities is negative (the conditions reduce entry into supervised other activity spells from other school related activities but do not hasten exit from supervised other activities). Having two working parents or a non-working father also increases girls' transition rates from unsupervised other activities to work. All of these results suggest that girls who live with both parents and whose mother works spend more time on educational and work activities and less time in supervised other activities. Living with a single parent is estimated to reduce girls' transitions from supervised other activities to non-classroom schooling activities and girls' transitions from unsupervised other activities to supervised other activities and to increase their transitions from unsupervised other activities to work. These results suggest that living with a single parent negatively affects the quality of girls' activities as measured by supervised and non-classroom schooling time. 
Table 4a shows that, among boys, having a working mother in a two parent household increases transitions out of non-classroom schooling activities into supervised other activities and that living with a single parent reduces transitions from work to supervised other activities, lengthening work spells. Table $4 \mathrm{~b}$ shows that living with a single parent increases transitions from supervised other time to unsupervised other time and generally reduces transitions out of unsupervised other time, increasing the length of unsupervised other activity spells.

The next key explanatory variable in the tables is parental education. Girls with more educated parents sleep later and have longer non-classroom schooling spells than girls with less educated parents. Parental education also increases girls' transitions from supervised and unsupervised other activities into non-classroom schooling activities. Among boys, having more educated parents also reduces the transition rate out of and increases the transition rate into these non-classroom schooling spells and also increases the transition rate into classroom activities.

For both girls and boys, the association between parental education and the amount of time spent in non-classroom schooling activities appears to be unambiguously positive.

Other elements of household structure are also associated with teenagers' time use. The presence of other children in the household generally increases the probability that teens will work and generally increases the amount of work time reported. These findings are not surprising given that we define 'work' to include child care and housework. Additional adults in the household tend to increase transitions to work as well, possibly at the cost of schooling activities.

Race and ethnicity are significantly associated with time use for all adolescents. Black girls have longer spells of unsupervised activities and of non-classroom schooling activities than non-black girls. There is also evidence, albeit imprecisely estimated, that black girls wake later. 
Looking at black boys, our results indicate they also wake later, but also that they are less likely to exit classroom schooling and more likely to exit other schooling. Black boys also have lower rates of transition from supervised other activities into work and from unsupervised activities into supervised other activities and into other schooling activities. In general, black teenagers appear to spend substantially more time in unsupervised other activities than other teenagers.

For Hispanic girls, there is also evidence of a time-shifted day with them both rising and going to bed later than non-Hispanic girls. Hispanic boys do not appear to be distinguishable from non-Hispanic boys in their sleep times. Hispanic girls are estimated to have longer classroom and other schooling activity spells than other girls. Indeed there is evidence that all Hispanic teens devote more time to schooling than other teens as Hispanic boys also have longer classroom and other schooling activity spells than other boys. For Hispanic boys, some of this comes at the expense of work spells as the coefficient estimates suggest they are less likely to enter work spells and more likely to exit them.

Higher unemployment rates are sometimes associated with household disadvantage but also with a shortage of work opportunities. A higher unemployment rate is associated here with shorter work spells for both girls and boys. For girls, poor job market conditions also contribute to fewer transitions from unsupervised activities to work and to longer spells of unsupervised activities overall. Among boys, higher unemployment is associated with shorter classroom spells but higher transition rates from unsupervised activities to other schooling activities.

As one might expect, age also matters. Older boys and girls rise later than younger teenagers but go to bed later, have longer spells of work, and are more likely to transition from unsupervised activities to work. Older teenage girls have shorter classroom spells. They are also less likely to transition from unsupervised other activities to classroom activities, less likely to 
transition from supervised activities to other schooling activities, and more likely to transition from supervised activities to classroom activities. Older boys are less likely to transition into classroom activities.

To control for dependencies across the uses of time, our models include the cumulative amounts of time that teenagers have spent so far during the day in certain activities as explanatory variables. Our results indicate that the cumulative time spent in an activity is a significant determinant of subsequent time use. For example, sleeping later in the morning is associated with a lower probability of continuing a classroom activity for girls and boys. Sleeping later is also associated with staying up later in the evening and with fewer transitions from unsupervised activities to work. For boys, sleeping later is associated with a lower rate of transitioning into classroom spells. For both boys and girls spells of classroom and other schooling activities early in the day are associated with a greater chance of transitioning into similar activities later in the day. However, for boys, early spells of classroom and other schooling activities contribute to shorter subsequent classroom spells.

Simulation results. The coefficients from Tables $3 \mathrm{a}-4 \mathrm{~b}$ are difficult to interpret. Each coefficient represents an estimated conditional association between an explanatory variable and an underlying index. The transition outcomes in the models depend on several indices and do so in a nonlinear way. The transition probabilities, in turn, are hard to interpret because they are expressed conditionally as hazard probabilities and further depend on the person's uses of time up to that possible transition. For example, the hazard at the eighth hour of an activity spell could be very high, but the practical impact could be negligible if few people continue in that activity for that long. Ultimately, we are interested in the associations of observed characteristics with teenagers' total daily time use, which depend cumulatively on the person's complete 
sequence of transitions.

To better examine the implications of the transition models, we conduct a series of simulations. The simulations apply the coefficient estimates from Tables $3 \mathrm{a}-4 \mathrm{~b}$ to samples in which we replicate each observation from the 2,009-person analysis sample 25 times. For each replicated observation, we simulate transitions between activities by calculating hazard probabilities at each point in time throughout a day conditioned on what was simulated for the person previously in the day. Each hazard is then compared to a random draw to simulate a possible transition. Time use patterns throughout the day and time use amounts for the entire day are then calculated based on the simulated transition paths. Using this methodology, Figure 2 illustrates the simulated distribution of time use across the day, while Figure 3 illustrates both the simulated and the actual distribution of daily hours by activity type. Baseline estimates of the fraction of individuals observed and the average amount of time spent in each of our six activities are reported at the top of Tables $5 \mathrm{a}$ and $5 \mathrm{~b}$.

Comparisons of the actual and simulated values of these different distributional elements are important because our models are fit to transitional probabilities and not specifically to these other characteristics. Nevertheless, we can see by comparing the first rows of Tables $5 \mathrm{a}$ and $5 \mathrm{~b}$ with the sample characteristics reported in Table 1 that the simulations do an excellent job of reproducing the average minutes and incidence of each of our activities. A comparison of Figures 1 and 2 reveals that the simulations also do a good job of capturing the distribution of teenagers' time use by time of day. The most noticeable feature that they appear to miss is a return to classroom activities on weekdays following lunch. Finally, in Figure 3, we see that we are able to simulate closely the distributions of total hours of activities during the day. As we had seen in Tables $5 \mathrm{a}$ and $5 \mathrm{~b}$, the incidence for all activities is accurately predicted. Figure 3 
additionally shows that the simulated distributions of hours for those predicted to engage in activities are nearly identical to the actual distributions for four of the six activities. For classroom activities, the simulations underpredict a spike in the distribution around seven hours, and for sleep, the simulations underpredict a peak around eight hours. An examination of Figure 3 also reveals advantages of our estimation technique relative to standard approaches. For example, standard OLS models are not constrained to predict non-negative hours, and they do not predict the incidence of activities. Standard Tobit models cannot predict a low or modest incidence of an activity with a peak in the continuous part of the distribution far from the origin. Two-part models typically reproduce the incidence of an activity well but fail to capture the continuous distribution.

We can also use simulations to examine the "marginal associations" of changes in the observed characteristics with the incidence and amount of time use. To do this, we systematically change characteristics from the analysis sample while holding the other observed characteristics fixed and then simulate the changes in the outcomes. Results from these simulations are reported in the second and subsequent rows of Table 5a for girls and Table 5b for boys. In addition to reporting the mean time and incidence for each change, we also report the percentage change in each from the relevant base case in parentheses below. In some cases we see that the change in incidence moves in the opposite direction from the change in amount. Single-index models are not able to capture such different effects.

The first four of these change simulations assign different family structures and parental work patterns to the teenagers. In particular, simulations are conducted assuming that all of the teenagers live in households with (1) two parents where the father works but the mother does not (the relevant base case for family structure/work pattern parameters), (2) two working parents, 
(3) two parents but a non-working father, and (4) a single parent. Relative to girls living with a working father and a non-working mother, the models indicate that girls living in other arrangements spend more time in work, less time in supervised other activities, and more time in unsupervised activities. Girls living with single parents also spend substantially less time in nonclassroom schooling activities. Boys living with two working parents spend less time in classroom and other schooling activities than boys living with a working father and a nonworking mother. Boys living with a single parent spend less time in other schooling activities, less time in supervised other activities, and substantially more time (over an hour more) in unsupervised activities. Boys living with both parents but whose father is not working appear to report a higher incidence of other schooling activity, but average less time in the activity.

Increased years of parental education are associated with both girls and boys spending additional time in other schooling activities. The marginal associations imply that children of parents with a bachelor's degree spend a quarter to a third of an hour more than children of parents with only a high school diploma on such activities. Parental education has little other association with teenagers' time use.

An additional child of any age increases teenage girls' average work time, with the largest effect occurring for an additional child aged 0-6. An additional child aged 0-6 also increases the time girls spend in supervised activities but decreases the time they spend in unsupervised activities and classroom and other schooling activities, suggesting that teenage girls may be required to help more around the house when young children are present. For boys, an additional child aged 0-6 increases the time spent in classroom activities and in unsupervised activities. An additional child aged 7-11 is estimated to increase boys' time in work activities by 26 minutes. While this does not change the probability of having supervised time, it does 
decrease the time spent in supervised activities by on average 13 minutes. Finally, an additional child aged 12-18 increases boys' time spent in work and supervised other activities while decreasing their time spent in unsupervised activities. Similarly, the presence of other adults contributes to a reallocation among boys from unsupervised to supervised other activities.

The simulations indicate that black girls and boys spend substantially more time in unsupervised other activities and less time in work and supervised other activities than non-black teenagers. Black boys also appear to spend significantly less time in classroom and other schooling activities. Hispanic boys spend more time in unsupervised other activities and nonclassroom schooling and less time in work and supervised other activities than non-Hispanics. Interestingly, Hispanic girls are a bit less likely to spend time either in the classroom or in other schooling, but when they do they spend substantially more time - over 30 more minutes in the class and almost 15 more minutes in other schooling. These results indicate that Hispanic and especially black teens are generally engaging in less schooling, less work, and less supervised activities, but more unsupervised activities than other teens.

Finally, the simulations reveal that higher unemployment rates are associated with less time in work and more time in unsupervised other activities. The association with work is stronger for boys, while the association with unsupervised other activities is stronger for girls.

$\underline{\text { Sensitivity analyses. }}$ The transition models presented in Tables $3 a-4 b$ incorporate numerous specialized controls, including controls for spell durations, cumulative time use, heaped reporting, and weekday and weekend/holiday time-of-day effects. Specification tests revealed that each set of controls was jointly significant and improved the fit of the models. To examine their substantive impact, we re-estimated the models without selected controls and then simulated the total daily time allocation distributions, as we had done with our preferred model. 
The alternative specifications did not reproduce the distributions as well as our preferred specification. Time-of-day controls were especially critical. Models without these controls substantially over-predicted sleep and under-predicted other activities. ${ }^{9}$

We also estimated transition models that included controls for unobserved heterogeneity, as described in equation (2). The unobserved components were specified as discrete distributions with two points of support. We estimated an "unrestricted" specification for girls and a partially restricted specification for boys. ${ }^{10}$ These led to small changes in the estimated duration effects but no appreciable changes in the estimated effects of the observed variables and other controls. The inclusion of these controls also did not alter the simulation results. Detailed results are available upon request.

\section{Conclusion}

We use time diaries from the 2003-2006 ATUS and an innovative application of competing-risk hazard models to examine how teenagers' daily time allocations are affected by family and personal characteristics. Our methodology has substantial advantages over other techniques. Analyzing activity spells within a hazard framework conforms to the way that activities in the ATUS and other time-diaries are reported, as a series of spells. In addition, our approach recognizes the mutually-exclusive nature of activities and the daily time constraint in a logically consistent way. It also allows us to distinguish between the incidence and the duration of an activity, and to incorporate time-of-day effects, heaped reporting, and some dependencies within and across activity spells. As a result, our competing risk hazard approach more closely

\footnotetext{
${ }^{9}$ The biggest issue was that these models predicted a constant rate of entry into retiring sleep, which is a terminal event. Once observations were simulated to enter this activity, they were not available to enter into other activities. ${ }^{10}$ Identification for these models requires at least one factor loading $\left(\lambda_{j k}\right.$ coefficient from specification 2$)$ to be fixed. The model for girls incorporated this minimal restriction; however, we were unable to obtain estimates of the model for boys unless a second factor was fixed.
} 
reproduces time-of-day patterns, the distributions of total daily activity times, and differences in the implied effects of observed characteristics on the incidence and total time allocation of activities than the approaches that have been applied in previous studies. Although our method of analyzing time diary data addresses many features of the data, we estimate our principal models using standard multinomial logit software. Thus, this approach can be easily implemented by most researchers.

We are especially interested in how characteristics associated with household disadvantage, such as living in a single-parent family or with an out-of-work father, living with less-educated parents, or living in a high unemployment area, affect teenagers' time investments in classroom activities and in other schooling activities. This distinction is critical as time devoted to other schooling activities appears to be sensitive to several aspects of disadvantage while time devoted to classroom activities is much less so. Our results indicate that teenagers of both sexes who lived in single parent families or with less-educated parents spent substantially less time in other schooling activities than other, comparable teenagers. Additionally, boys who lived with two working parents devoted less time to other schooling activities than boys who lived with a working father but a non-working mother, and black boys were estimated to spend less than half as much time as white boys in these activities. While the ATUS data are limited to a single day's time allocations and thus lack long-run outcome measures such as standardized test scores and future labor market outcomes, these results suggest that one potential mechanism through which disadvantage negatively affects future outcomes is through reduced homework time and reduced participation in extracurricular activities.

We are also keenly interested in how household disadvantage alters teenagers' other uses of time. Given the daily time constraint, these reductions in schooling investments must be 
counterbalanced by increases in other uses of time. Prior research has only addressed offsetting time use in a limited way if at all. A key advantage of our approach is that it naturally incorporates all uses of time. In particular, we group teenagers' non-schooling activities into four categories: work, sleep, other activities where an adult is present and available to supervise, and other activities without an adult. This decomposition, in turn, facilitates an investigation of two hypotheses regarding why disadvantage might affect schooling. The first hypothesis is that teenagers in disadvantaged households might have to adopt adult roles and take on extra economic or household responsibilities. This could result in their work hours increasing. The second hypothesis is that disadvantaged households may provide less supervision or provide less structured environments, leading teenagers to spend more time in unsupervised other activities.

We find some evidence supporting the early-adult-role hypothesis for girls. Girls who live in single parent households, but also those who live in two-parent households with a working mother or a non-working father, devote 12-15 more minutes to work than girls in traditional households. Girls with very young siblings also work more than other girls.

We find much more evidence for the supervision/structure hypothesis, especially for boys. Boys living in single parent households are estimated to spend nearly an hour and 15 minutes more per day in unsupervised other activities than boys living with a working father and a non-working mother. For girls, this same difference in living arrangements is associated with a third of an hour increase in unsupervised activities.

Evidence regarding supervision and structure also can be seen in other ways such as the timing of teenagers' days and employment tradeoffs. Girls with less educated parents tend to sleep later than other girls. Black boys and Hispanic girls follow a similar pattern. Higher local unemployment rates and minority status reduce work time generally. To a substantial degree the 
reduction in work time is offset by an increase in unsupervised time.

The less structured environment of disadvantaged youths may therefore be a key mechanism explaining their reduced investment in education. Policy initiatives designed to provide more structure and supervision may help ameliorate this differential. These would include mentoring programs, such as Big Brothers and Big Sisters, for teens in single-parent households. They might also include after-school programs, such as homework clubs and intensive tutoring, for teens with working and/or less educated parents. These could provide both educational assistance and structure to enhance schooling achievement. Counseling and workshop programs for disadvantaged parents may also help them to supervise more effectively. In addition, our findings regarding girls' work suggest that their schooling might benefit from expanded day care facilities for their younger siblings. 


\section{References}

Allison, Paul D. 1982. "Discrete-Time Methods for the Analysis of Event Histories." Sociological Methodology, 13: 61-98.

Bowles, Samuel; Herbert Gintis and Melissa Osborne Groves, eds. 2005. Unequal Chances: Family Background and Economic Success. New York: Russell Sage Foundation.

Brayfield, April. 1995. "Juggling Jobs and Kids: The Impact of Employment Schedules on Fathers' Caring for Children." Journal of Marriage and the Family, 57(2): 321-32.

Bryant, W. Keith and Cathleen D. Zick. 1996. "An Examination of Parent-Child Shared Time.” Journal of Marriage and the Family, 58(1): 227-37.

Call, Kathleen Thiede; Jeylan T. Mortimer; and Michael J. Shanahan. 1995. "Helpfulness and the Development of Competence in Adolescence.” Child Development, 66(1): 129-138.

Capizzano, Jeffrey; Regan Main and Sandi Nelson. 2004. “Adolescents Assuming Adult Roles: Factors Associated with Teens Providing Child Care for Younger Siblings." Unpublished manuscript. Washington, DC: The Urban Institute.

Demo, David H. and Alan C. Acock. 1993. "Family Diversity and the Division of Domestic Labor: How Much Have Things Really Changed?" Family Relations, 42(3): 323-331.

Duncan, Greg J. and Jeanne Brooks-Gunn, eds. 1997. Consequences of Growing Up Poor. New York: Russell Sage Foundation.

Furstenberg, Frank F. 2000. "The Sociology of Adolescence and Youth in the 1990s: A Critical Commentary." Journal of Marriage and the Family, 62(4): 896-910.

Gager, Constance T.; Teresa M. Cooney; and Kathleen Thiede Call. 1999. "The Effects of Family Characteristics and Time Use on Teenagers' Household Labor.” Journal of Marriage and the Family, 61(4): 982-94. 
Gennetian, Lisa A.; Greg J. Duncan; Virginia W. Knox; Wanda G. Vargas; Elizabeth ClarkKauffman; and Andrew S. London. 2002. "How Welfare and Work Policies for Parents Affect Adolescents: A Synthesis of Research.” MDRC report.

Goldscheider, Frances K. and Linda J. Waite. 1991. "New Families, No Families? The Transformation of the American Home.” Berkeley: University of California Press.

Hamermesh, Daniel S. (1999). "The Timing of Work over Time." Economic Journal, 109(542): $37-66$. . 2005. "Routine.” European Economic Review, 49(1): 29-53.

Haveman, Robert and Barbara Wolfe. 1994. Succeeding Generations: On the Effects of Investments in Children. New York: Russell Sage Foundation.

Heckman, James J. and Burton Singer. 1984. “A Method for Minimizing the Impact of Distributional Assumptions in Econometric Models of Duration Data." Econometrica, 52(2): 271-320.

Hilton, Jeanne M. and Virginia A. Haldeman. 1991. "Gender Differences in the Performance of Household Tasks by Adults and Children in Single-Parent and Two-Parent, Two-Earner Families.” Journal of Family Issues, 12(1): 114-30.

Kalenkoski, Charlene M. and Sabrina W. Pabilonia. 2009a. "Does Working While in High School Reduce Study Time in the U.S.?" Social Indicators Research, 93(1): 117-121. . 2009b. "Time to Work or Time to Play: The Effect of Student Employment on Homework, Screen Time, and Sleep.” Unpublished manuscript.

Kalenkoski, Charlene M., David C. Ribar and Leslie S. Stratton. 2005. "Parental Child Care in Single Parent, Cohabiting, and Married Couple Families: Time Diary Evidence from the United Kingdom.” American Economic Review Papers and Proceedings, 95(2): 194-8. 
. 2007. "The Effect of Family Structure on Parents' Child Care Time in the United

States and the United Kingdom." Review of Economics of the Household, 5(4): 353-384.

Leventhal, Tama; Julia A. Graber; and Jeanne Brooks-Gunn. 2001. “Adolescent Transitions to

Young Adulthood: Antecedents, Correlates, and Consequences of Adolescent

Employment.” Journal of Research on Adolescence, 11(3): 297-323.

Lillard, Lee and Constantijn Panis. 2003. aML Multilevel Multiprocess Statistical Software, Version 2.0. Los Angeles, CA: EconWare, Inc.

Marshall, Katherine. 2007. "The Busy Lives of Teenagers.” Perspectives: 5-15.

Oettinger, Gerald S. 1999. "Does High School Employment Affect High School Academic Performance?" Industrial and Labor Relations Review 53(1): 136-151.

Peters, Jeanne M. and Virginia A. Haldeman. 1987. “Time Used for Household Work.” Journal of Family Issues, 8(2): 212-25.

Porterfield, Shirley L. and Anne E. Winkler. 2007. "Teen Time Use and Parental Education: Evidence from the CPS, MTF, and ATUS.” Monthly Labor Review, 130(5): 37-56.

Presser, Harriet. 1986. "Shift Work among American Women and Child Care." Journal of Marriage and the Family, 48(3): 551-63.

. 1988. "Shift Work and Child Care among Young Dual-Earner American Parents." Journal of Marriage and the Family, 50(1): 133-48. . 1994. "Employment Schedules Among Dual-Earner Spouses and the Division of Household Labor by Gender.” American Sociological Review, 59(3): 348-64.

Price, Joseph; Bijou Hunt; Vanessa Wight; and Suzanne Bianchi. 2007. “The Time Use of Teenagers." Unpublished manuscript.

Rothstein, Donna S. 2007. "High School Employment and Youths' Academic Achievement." 
Journal of Human Resources, 42(1): 194-213.

Ruhm, Christopher J. 1995. "The Extent and Consequences of High School Employment.” Journal of Labor Research, 16(3): 293-304. . 1997. "Is High School Employment Consumption or Investment?" Journal of Labor Economics, 15(4): 735-776.

Tyler, John H. 2003. "Using State Child Labor Laws to Identify the Effect of School-Year Work on High School Achievement," Journal of Labor Economics 21(2): 353-380.

Zick, Cathleen D. 2007. "Over-Scheduled or at Loose Ends? The Shifting Balance of Adolescent Time Use.” Unpublished manuscript. 
Figure 1. Distributions of teenagers' time use across the day during the school year

a. Teenage girls - non-holiday weekdays

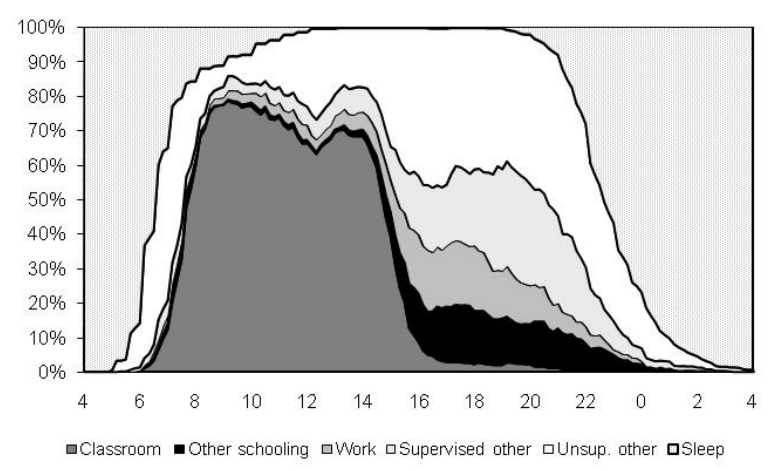

c. Teenage boys - non-holiday weekdays

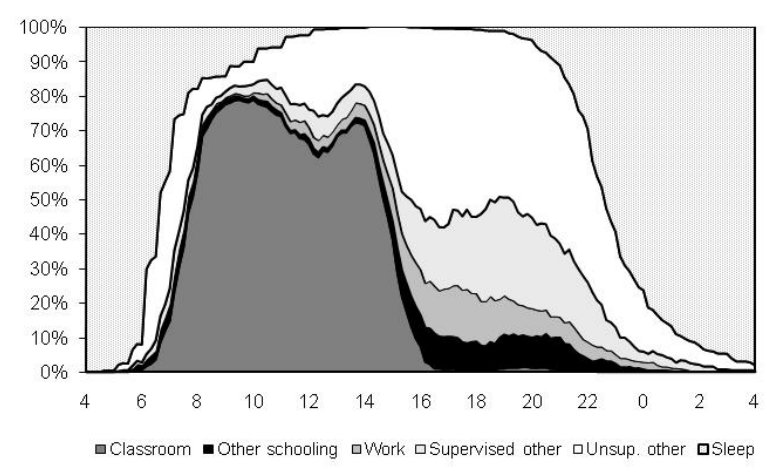

b. Teenage girls - weekend days, holidays

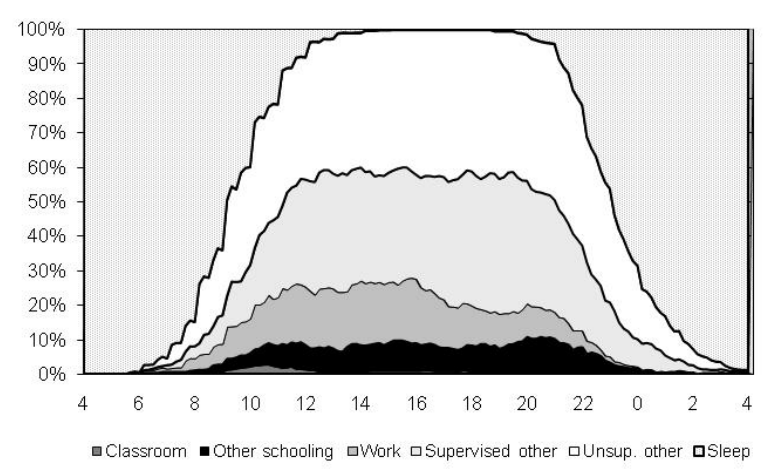

d. Teenage boys - weekend days, holidays

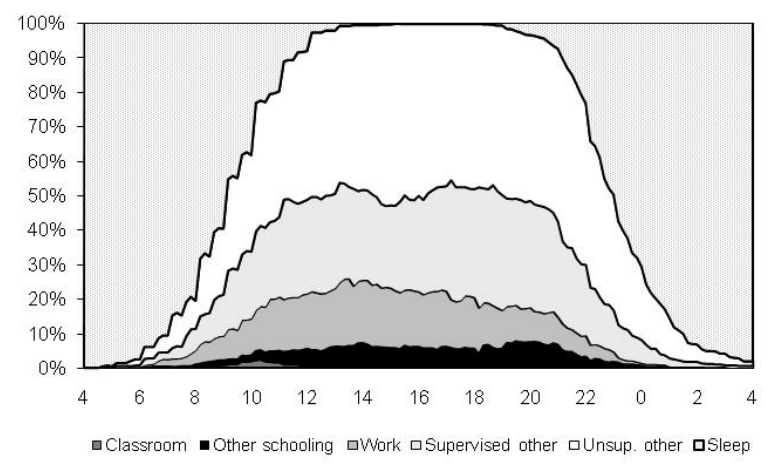

Notes: Statistics calculated using school-year data for enrolled high school students from the 2003-6 ATUS; statistics incorporate sampling weights supplied with ATUS. 
Figure 2. Simulated distributions of teenagers' time use across the day during the school year

a. Teenage girls - non-holiday weekdays

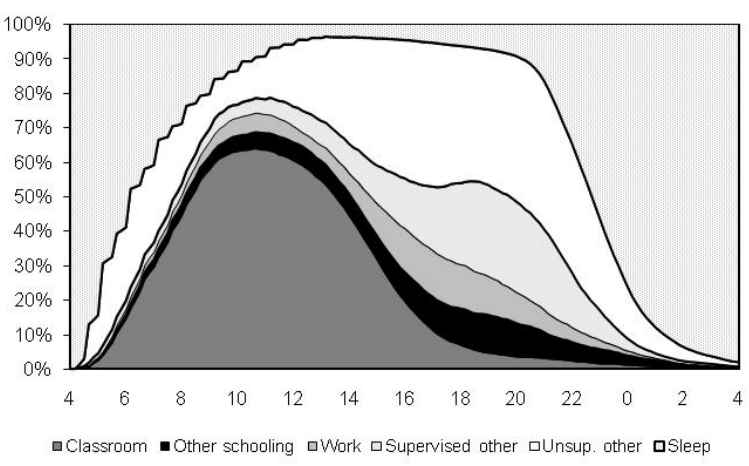

c. Teenage boys - non-holiday weekdays

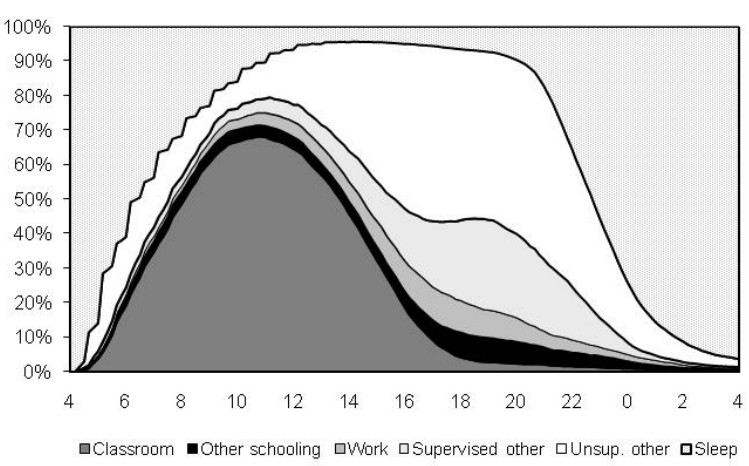

b. Teenage girls - weekend days, holidays

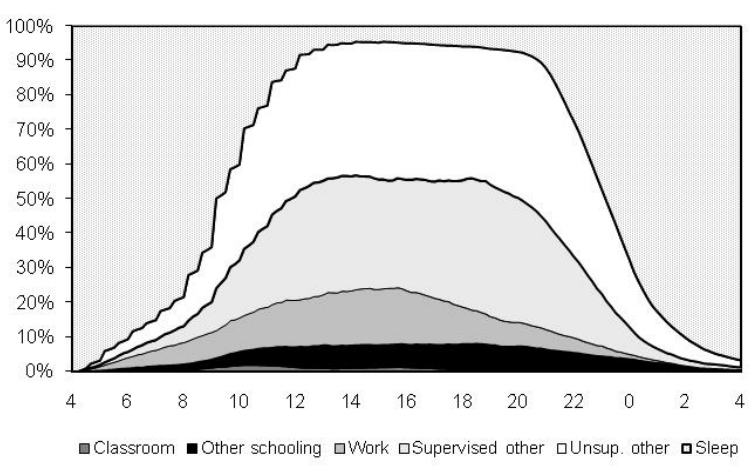

d. Teenage boys - weekend days, holidays

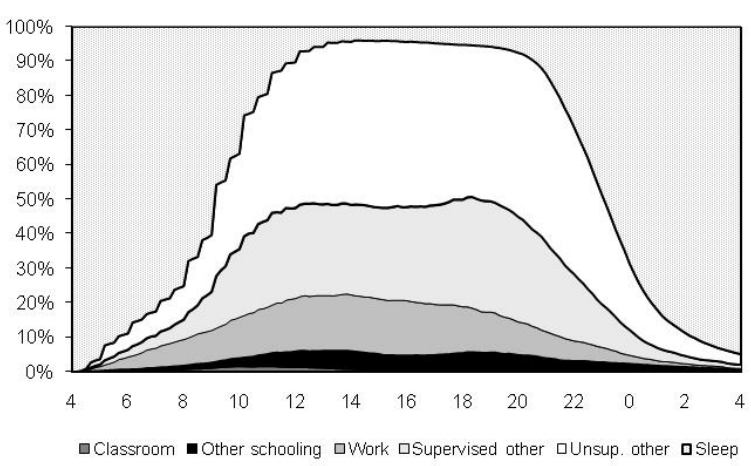

Notes: Simulated distributions calculated using school-year data for enrolled high school students from the 2003-6 ATUS and coefficient estimates from Tables 3a-4b. Statistics incorporate sampling weights supplied with the ATUS. 
Figure 3. Distributions of teenagers' actual and simulated total hours in different activities

a. Teenage girls - classroom activities

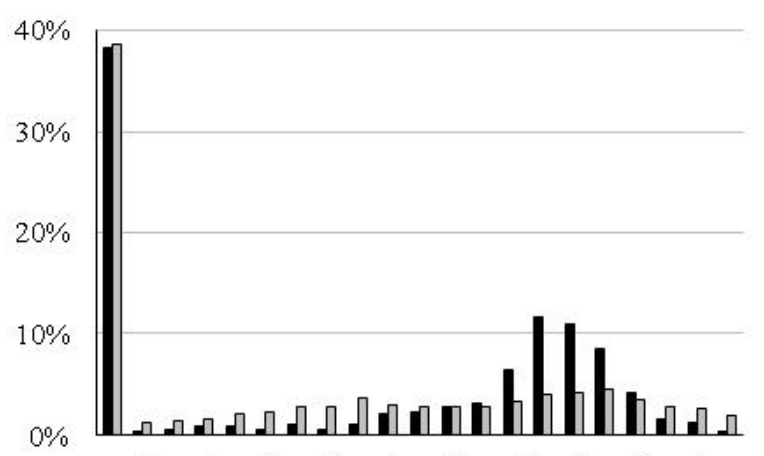

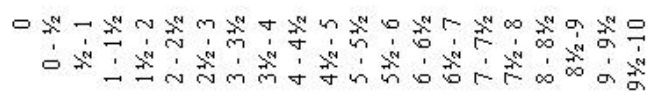

- Actual $\square$ Predicted

c. Teenage girls - other schooling activities

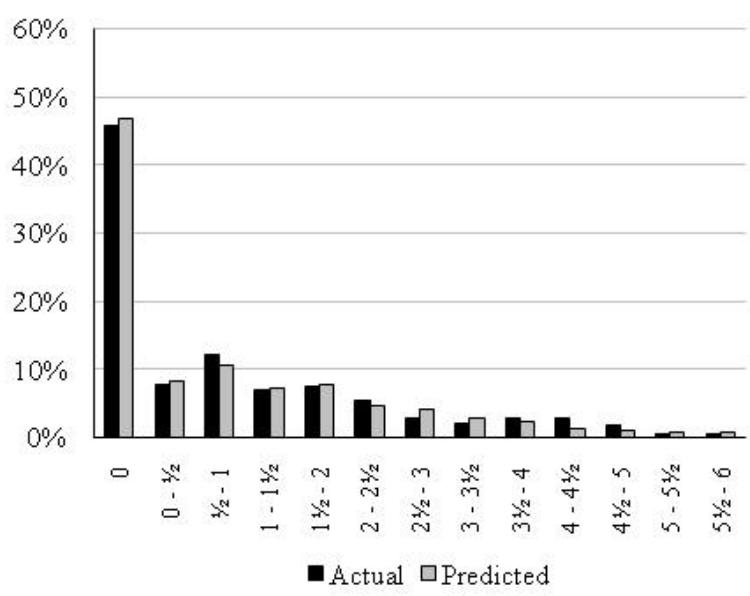

e. Teenage girls - work activities

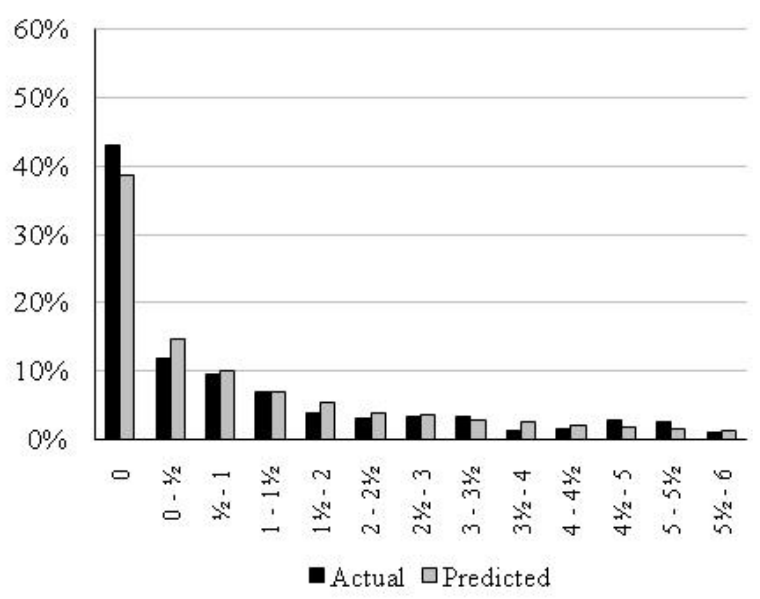

b. Teenage boys - classroom activities

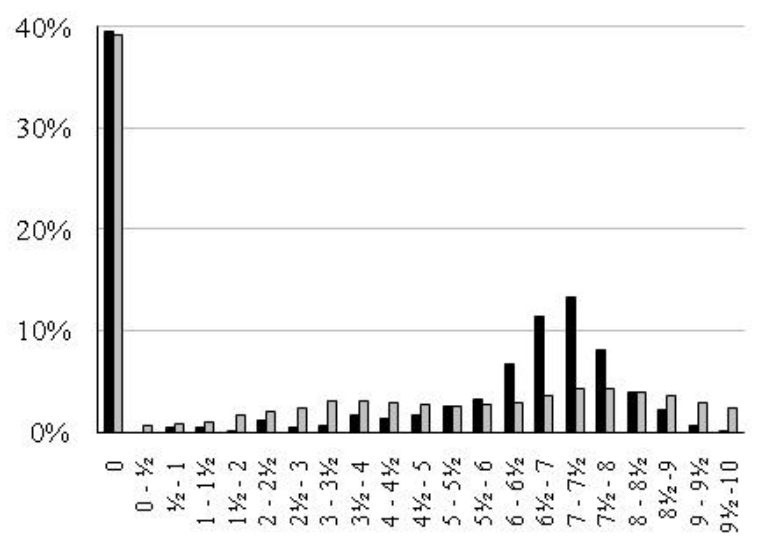

Actual $\square$ Predicted

d. Teenage boys - other schooling activities

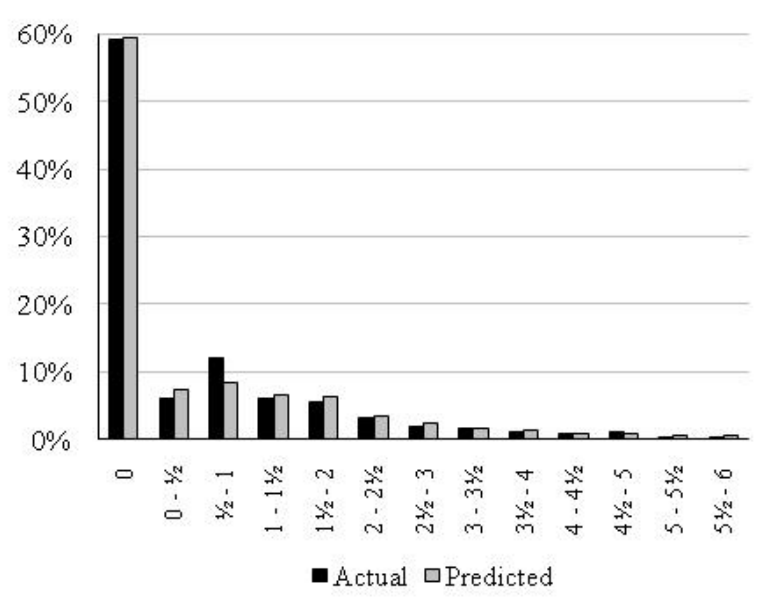

f. Teenage boys - work activities

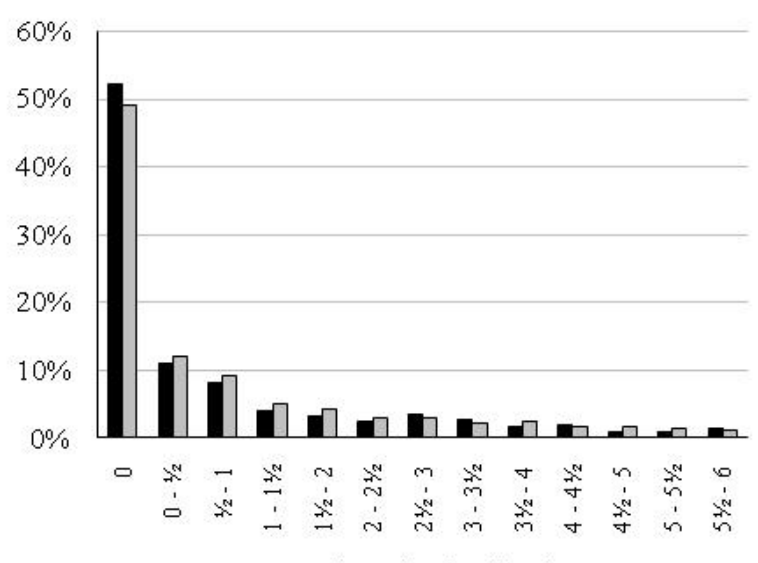

- Actual $\square$ Predicted

34 
g. Teenage girls - supervised other activities

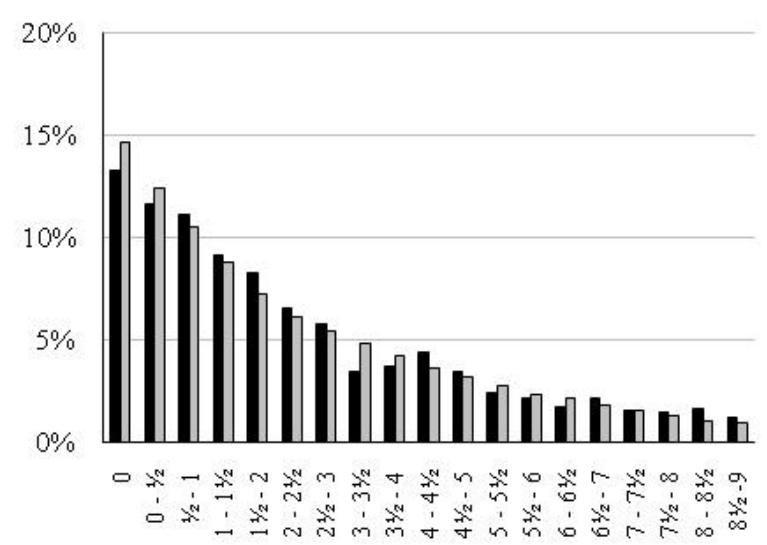

- Actual $\square$ Predicted

i. Teenage girls - unsupervised other activities

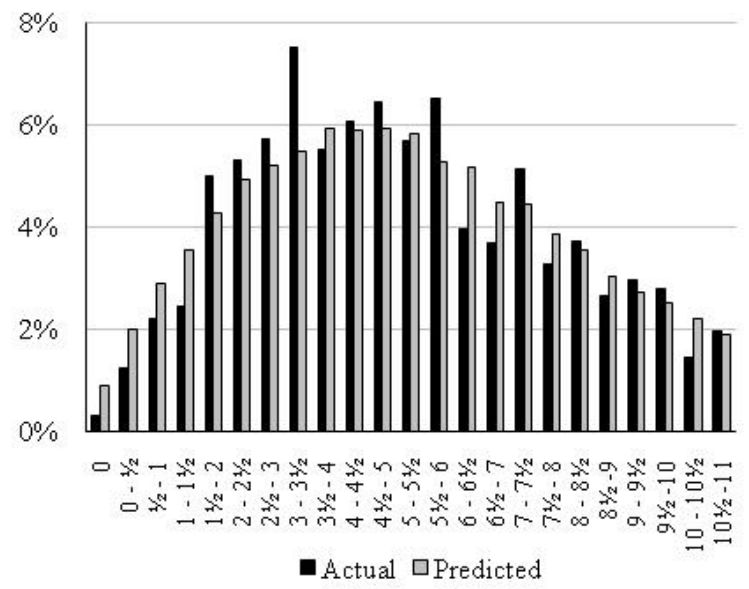

k. Teenage girls - sleep

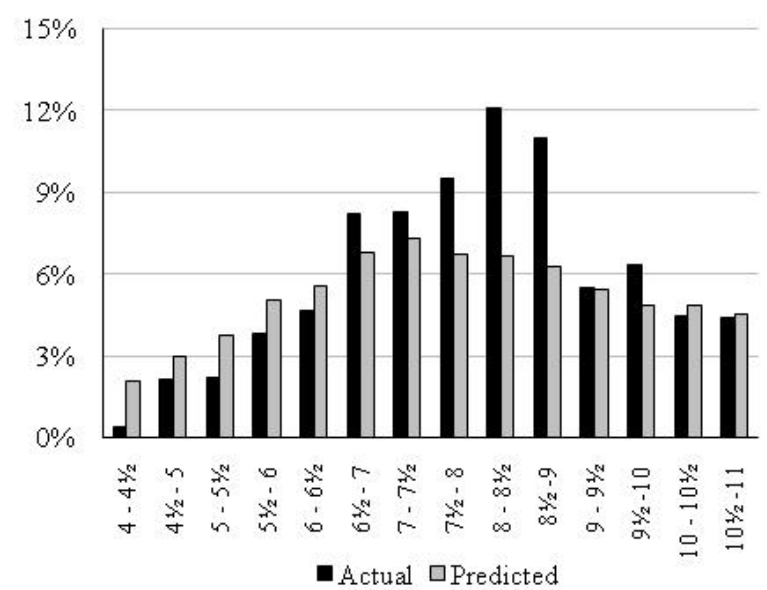

h. Teenage boys - supervised other activities

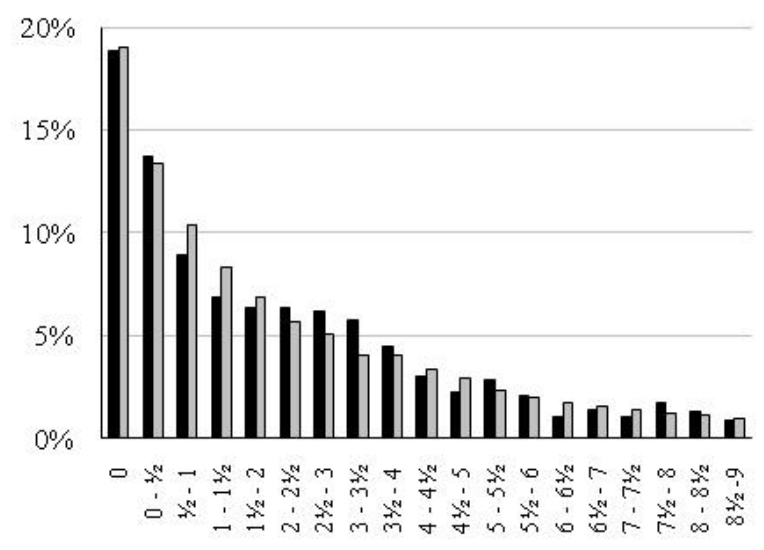

- Actual $\square$ Predicted

j. Teenage boys - unsupervised other activities

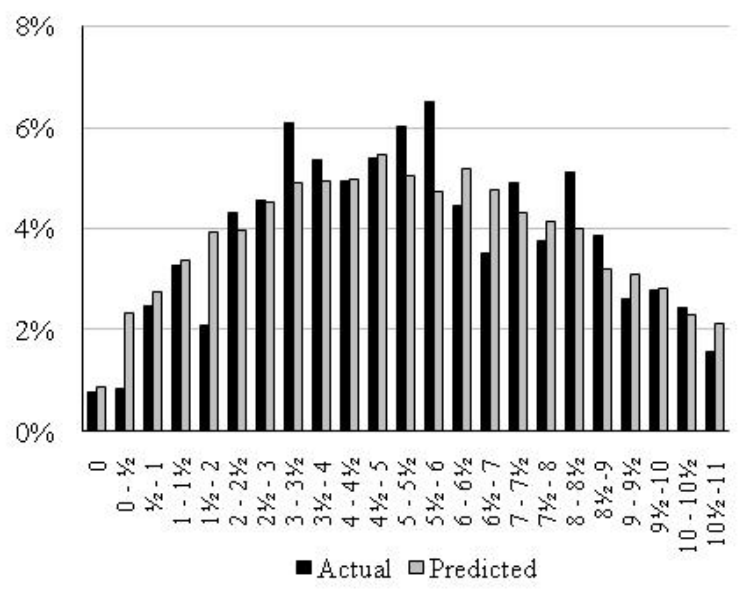

1. Teenage boys - sleep

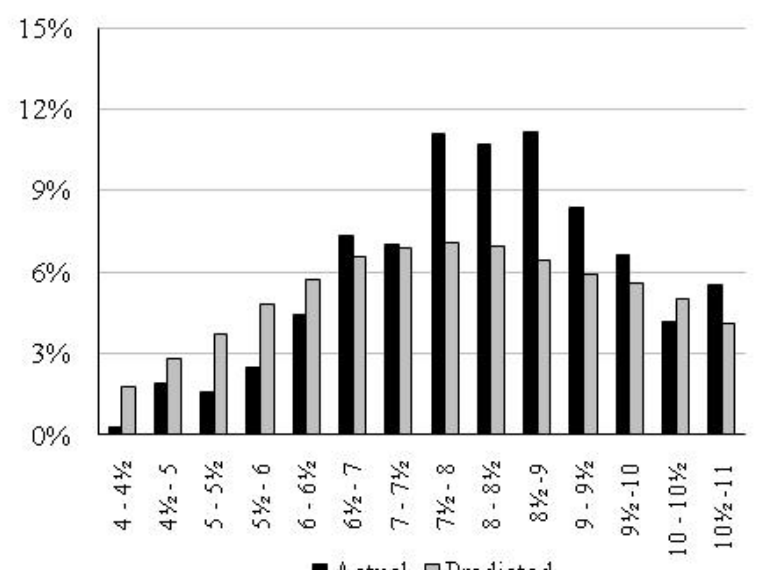

Notes: Simulated distributions calculated using school-year data for enrolled high school students from the 2003-6 ATUS and coefficient estimates from Tables 3a-4b. Statistics incorporate sampling weights supplied with ATUS. 
Table 1. Means and Standard Deviations of Analysis Variables

\begin{tabular}{|c|c|c|c|c|}
\hline & \multicolumn{2}{|c|}{ Teenage girls } & \multicolumn{2}{|c|}{ Teenage boys } \\
\hline & Mean & Std. dev. & Mean & Std. dev. \\
\hline \multicolumn{5}{|l|}{ Outcome Variables } \\
\hline Minutes spent in classroom activities & 245.65 & 212.00 & 243.99 & 210.70 \\
\hline Any time in classroom activities & 0.62 & 0.49 & 0.61 & 0.49 \\
\hline Minutes spent in other schooling activities & 68.90 & 96.02 & 46.45 & 83.51 \\
\hline Any time in other schooling activities & 0.54 & 0.50 & 0.41 & 0.49 \\
\hline Minutes spent in household or market work & 89.19 & 134.25 & 80.58 & 143.76 \\
\hline Any time in household or market work & 0.57 & 0.50 & 0.48 & 0.50 \\
\hline Minutes spent in other supervised activities & 173.72 & 180.56 & 161.37 & 184.64 \\
\hline Any time in other supervised activities & 0.87 & 0.34 & 0.81 & 0.39 \\
\hline Minutes spent in other unsupervised activities & 350.50 & 200.32 & 387.77 & 221.21 \\
\hline Any time in other unsupervised activities & 1.00 & 0.06 & 0.99 & 0.09 \\
\hline Minutes spent in sleep & 524.04 & 136.42 & 530.12 & 140.54 \\
\hline \multicolumn{5}{|l|}{ Explanatory Variables } \\
\hline Two-parent household, only father works ${ }^{a}$ & 0.19 & 0.39 & 0.18 & 0.38 \\
\hline Two-parent household, both parents work & 0.50 & 0.50 & 0.50 & 0.50 \\
\hline Two-parent household, father does not work & 0.07 & 0.26 & 0.09 & 0.29 \\
\hline Single-parent household & 0.24 & 0.42 & 0.23 & 0.42 \\
\hline Highest education obtained by parents & 14.13 & 3.10 & 13.96 & 3.08 \\
\hline Number of children aged $0-6$ in household & 0.15 & 0.46 & 0.14 & 0.41 \\
\hline Number of children aged 7-11 in household & 0.30 & 0.56 & 0.28 & 0.54 \\
\hline Number of children aged 12-18 in household & 0.74 & 0.81 & 0.74 & 0.76 \\
\hline Number of other adults in household & 0.37 & 0.67 & 0.42 & 0.72 \\
\hline Hispanic & 0.16 & 0.37 & 0.19 & 0.39 \\
\hline Black & 0.13 & 0.33 & 0.13 & 0.34 \\
\hline Age & 16.32 & 1.00 & 16.37 & 1.01 \\
\hline Urban & 0.84 & 0.37 & 0.82 & 0.38 \\
\hline State unemployment rate & 5.30 & 1.10 & 5.39 & 1.03 \\
\hline Weekend or holiday & 0.28 & 0.45 & 0.28 & 0.45 \\
\hline Year $=2003^{a}$ & 0.33 & 0.47 & 0.33 & 0.47 \\
\hline Year $=2004$ & 0.21 & 0.41 & 0.25 & 0.43 \\
\hline Year $=2005$ & 0.19 & 0.39 & 0.20 & 0.40 \\
\hline Year $=2006$ & 0.26 & 0.44 & 0.22 & 0.42 \\
\hline Number of respondents & \multicolumn{2}{|c|}{1004} & \multicolumn{2}{|c|}{1005} \\
\hline
\end{tabular}

Notes: Statistics calculated using school-year data for enrolled high-school students from the 2003-6 ATUS; statistics incorporate sampling weights supplied with ATUS.

${ }^{a}$ Omitted category in multivariate analyses. 
Table 2. Numbers and percentages of interval transitions

a. Teenage girls

\begin{tabular}{|c|c|c|c|c|c|c|c|}
\hline & \multicolumn{6}{|c|}{ Destination activity } \\
\hline & & Classroom & $\begin{array}{c}\text { Other } \\
\text { schooling }\end{array}$ & Work & $\begin{array}{c}\text { Supervised } \\
\text { other }\end{array}$ & $\begin{array}{l}\text { Unsupervised } \\
\text { other }\end{array}$ & Sleep \\
\hline \multirow{6}{*}{$\begin{array}{l}\text { Origin } \\
\text { activity }\end{array}$} & Sleep & $\begin{array}{c}17 \\
0.01\end{array}$ & $\begin{array}{c}5 \\
<\mathbf{0 . 0 1}\end{array}$ & $\begin{array}{c}57 \\
\mathbf{0 . 0 4}\end{array}$ & $\begin{array}{c}94 \\
\mathbf{0 . 0 6}\end{array}$ & $\begin{array}{c}831 \\
0.57\end{array}$ & $\begin{array}{l}51609 \\
35.40\end{array}$ \\
\hline & Classroom & $\begin{array}{c}23583 \\
\mathbf{1 6 . 1 8}\end{array}$ & $\begin{array}{l}135 \\
0.09\end{array}$ & $\begin{array}{c}98 \\
\mathbf{0 . 0 7}\end{array}$ & $\begin{array}{l}152 \\
0.10\end{array}$ & $\begin{array}{l}695 \\
0.48\end{array}$ & $\begin{array}{c}1 \\
<0.01\end{array}$ \\
\hline & $\begin{array}{l}\text { Other } \\
\text { schooling }\end{array}$ & $\begin{array}{c}81 \\
0.06\end{array}$ & $\begin{array}{l}6102 \\
\mathbf{4 . 1 9}\end{array}$ & $\begin{array}{c}68 \\
0.05\end{array}$ & $\begin{array}{l}177 \\
0.12\end{array}$ & $\begin{array}{l}419 \\
0.29\end{array}$ & $\begin{array}{c}71 \\
\mathbf{0 . 0 5}\end{array}$ \\
\hline & Work & $\begin{array}{c}25 \\
0.02\end{array}$ & $\begin{array}{c}73 \\
0.05\end{array}$ & $\begin{array}{l}7946 \\
5.45\end{array}$ & $\begin{array}{l}306 \\
0.21\end{array}$ & $\begin{array}{l}575 \\
0.39\end{array}$ & $\begin{array}{c}30 \\
0.02\end{array}$ \\
\hline & $\begin{array}{l}\text { Supervised } \\
\text { other }\end{array}$ & $\begin{array}{l}109 \\
\mathbf{0 . 0 7}\end{array}$ & $\begin{array}{l}205 \\
0.14\end{array}$ & $\begin{array}{l}263 \\
0.18\end{array}$ & $\begin{array}{l}15641 \\
10.73\end{array}$ & $\begin{array}{l}1047 \\
0.72\end{array}$ & $\begin{array}{l}176 \\
0.12\end{array}$ \\
\hline & $\begin{array}{l}\text { Unsuper. } \\
\text { other }\end{array}$ & $\begin{array}{l}849 \\
\mathbf{0 . 5 8}\end{array}$ & $\begin{array}{l}399 \\
0.27\end{array}$ & $\begin{array}{l}523 \\
0.36\end{array}$ & $\begin{array}{l}1072 \\
0.74\end{array}$ & $\begin{array}{l}31630 \\
21.70\end{array}$ & $\begin{array}{l}717 \\
\mathbf{0 . 4 9}\end{array}$ \\
\hline
\end{tabular}

b. Teenage boys

Destination activity

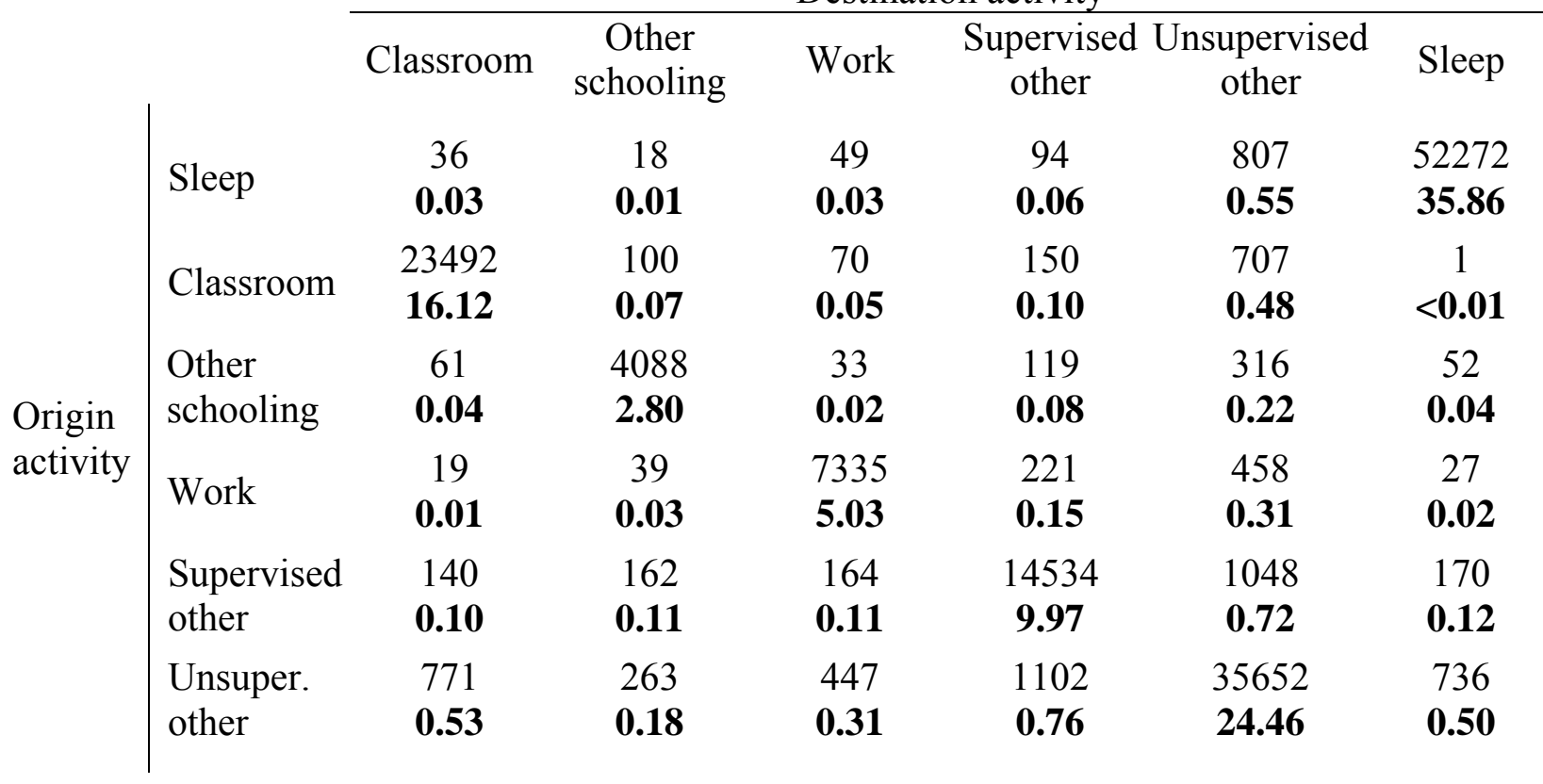

Note: Authors' calculations from the 2003-6 ATUS. Numbers of transitions appear in regular font and percentages appear in bold. Calculations incorporate sampling weights. 
Table 3a: Coefficient Estimates for Transitions to Supervised and Unsupervised Other Activities: Girls

\begin{tabular}{|c|c|c|c|c|c|c|c|c|}
\hline \multirow{2}{*}{$\begin{array}{l}\text { Initial State: } \\
\text { Ending State: }\end{array}$} & \multicolumn{2}{|c|}{ Initial Sleep } & \multicolumn{2}{|c|}{ Classroom } & \multicolumn{2}{|c|}{ Other Schooling } & \multicolumn{2}{|c|}{ Work } \\
\hline & $\begin{array}{l}\text { Supervised } \\
\text { other time }\end{array}$ & $\begin{array}{l}\text { Unsuper. } \\
\text { other time }\end{array}$ & $\begin{array}{l}\text { Supervised } \\
\text { other time }\end{array}$ & $\begin{array}{l}\text { Unsuper. } \\
\text { other time }\end{array}$ & $\begin{array}{l}\text { Supervised } \\
\text { other time }\end{array}$ & $\begin{array}{l}\text { Unsuper. } \\
\text { other time }\end{array}$ & $\begin{array}{l}\text { Supervised } \\
\text { other time }\end{array}$ & $\begin{array}{l}\text { Unsuper. } \\
\text { other time }\end{array}$ \\
\hline $\begin{array}{l}\text { Two-parent household, } \\
\text { both parents work }\end{array}$ & $\begin{array}{l}-0.092 \\
(0.281)\end{array}$ & $\begin{array}{c}0.034 \\
(0.103)\end{array}$ & $\begin{array}{c}-0.626 * * * \\
(0.219)\end{array}$ & $\begin{array}{l}-0.125 \\
(0.106)\end{array}$ & $\begin{array}{l}-0.308 \\
(0.202)\end{array}$ & $\begin{array}{l}-0.091 \\
(0.143)\end{array}$ & $\begin{array}{l}-0.234 \\
(0.183)\end{array}$ & $\begin{array}{l}-0.080 \\
(0.145)\end{array}$ \\
\hline $\begin{array}{l}\text { Two-parent household, } \\
\text { father does not work }\end{array}$ & $\begin{array}{l}-1.025 \\
(0.658)\end{array}$ & $\begin{array}{l}0.127 \\
(0.164)\end{array}$ & $\begin{array}{l}-0.782 * \\
(0.415)\end{array}$ & $\begin{array}{c}0.158 \\
(0.177)\end{array}$ & $\begin{array}{l}-0.697 * \\
(0.401)\end{array}$ & $\begin{array}{c}0.031 \\
(0.234)\end{array}$ & $\begin{array}{l}-0.135 \\
(0.264)\end{array}$ & $\begin{array}{l}-0.155 \\
(0.217)\end{array}$ \\
\hline Single-parent household & $\begin{array}{l}-0.295 \\
(0.340)\end{array}$ & $\begin{array}{l}-0.067 \\
(0.122)\end{array}$ & $\begin{array}{l}-0.305 \\
(0.257)\end{array}$ & $\begin{array}{l}-0.129 \\
(0.128)\end{array}$ & $\begin{array}{l}-0.400 \\
(0.300)\end{array}$ & $\begin{array}{c}0.214 \\
(0.182)\end{array}$ & $\begin{array}{l}-0.080 \\
(0.212)\end{array}$ & $\begin{array}{l}-0.025 \\
(0.163)\end{array}$ \\
\hline $\begin{array}{l}\text { Highest education obtained } \\
\text { by parents }\end{array}$ & $\begin{array}{l}-0.066 * \\
(0.040)\end{array}$ & $\begin{array}{l}0.005 \\
(0.014)\end{array}$ & $\begin{array}{l}-0.045 \\
(0.031)\end{array}$ & $\begin{array}{c}0.017 \\
(0.015)\end{array}$ & $\begin{array}{l}-0.052 * \\
(0.029)\end{array}$ & $\begin{array}{l}-0.027 \\
(0.020)\end{array}$ & $\begin{array}{c}0.039 \\
(0.024)\end{array}$ & $\begin{array}{c}0.005 \\
(0.018)\end{array}$ \\
\hline Number of children aged 0-6 & $\begin{array}{l}-0.041 \\
(0.288)\end{array}$ & $\begin{array}{l}-0.094 \\
(0.090)\end{array}$ & $\begin{array}{l}-0.235 \\
(0.219)\end{array}$ & $\begin{array}{l}-0.119 \\
(0.099)\end{array}$ & $\begin{array}{l}-0.133 \\
(0.279)\end{array}$ & $\begin{array}{c}0.004 \\
(0.164)\end{array}$ & $\begin{array}{c}0.118 \\
(0.119)\end{array}$ & $\begin{array}{c}0.079 \\
(0.087)\end{array}$ \\
\hline Number of children aged 7-11 & $\begin{array}{l}-0.162 \\
(0.231)\end{array}$ & $\begin{array}{c}0.029 \\
(0.073)\end{array}$ & $\begin{array}{l}-0.217 \\
(0.175)\end{array}$ & $\begin{array}{l}0.051 \\
(0.074)\end{array}$ & $\begin{array}{l}-0.164 \\
(0.181)\end{array}$ & $\begin{array}{l}-0.058 \\
(0.112)\end{array}$ & $\begin{array}{l}0.110 \\
(0.109)\end{array}$ & $\begin{array}{l}0.167 * * \\
(0.081)\end{array}$ \\
\hline $\begin{array}{l}\text { Number of children aged } \\
12-18\end{array}$ & $\begin{array}{l}-0.202 \\
(0.155)\end{array}$ & $\begin{array}{c}0.024 \\
(0.049)\end{array}$ & $\begin{array}{l}-0.018 \\
(0.108)\end{array}$ & $\begin{array}{l}-0.049 \\
(0.049)\end{array}$ & $\begin{array}{c}0.042 \\
(0.107)\end{array}$ & $\begin{array}{c}0.042 \\
(0.070)\end{array}$ & $\begin{array}{l}-0.073 \\
(0.084)\end{array}$ & $\begin{array}{c}0.077 \\
(0.062)\end{array}$ \\
\hline Number of other adults & $\begin{array}{l}-0.166 \\
(0.199)\end{array}$ & $\begin{array}{c}0.054 \\
(0.057)\end{array}$ & $\begin{array}{c}0.106 \\
(0.150)\end{array}$ & $\begin{array}{l}0.157 * * \\
(0.068)\end{array}$ & $\begin{array}{l}-0.011 \\
(0.149)\end{array}$ & $\begin{array}{c}0.063 \\
(0.092)\end{array}$ & $\begin{array}{l}-0.093 \\
(0.092)\end{array}$ & $\begin{array}{l}-0.044 \\
(0.062)\end{array}$ \\
\hline Hispanic & $\begin{array}{c}-1.058 * * * \\
(0.403)\end{array}$ & $\begin{array}{l}-0.078 \\
(0.116)\end{array}$ & $\begin{array}{c}-0.963 * * * \\
(0.304)\end{array}$ & $\begin{array}{l}-0.398 * * * \\
(0.136)\end{array}$ & $\begin{array}{l}-0.625 * * \\
(0.299)\end{array}$ & $\begin{array}{l}-0.293 \\
(0.180)\end{array}$ & $\begin{array}{c}0.179 \\
(0.174)\end{array}$ & $\begin{array}{c}0.152 \\
(0.136)\end{array}$ \\
\hline Black & $\begin{array}{l}-0.714 \\
(0.445)\end{array}$ & $\begin{array}{c}0.089 \\
(0.124)\end{array}$ & $\begin{array}{l}-0.382 \\
(0.312)\end{array}$ & $\begin{array}{l}-0.095 \\
(0.127)\end{array}$ & $\begin{array}{l}-0.654 * * \\
(0.328)\end{array}$ & $\begin{array}{l}-0.062 \\
(0.182)\end{array}$ & $\begin{array}{l}-0.140 \\
(0.217)\end{array}$ & $\begin{array}{c}0.142 \\
(0.139)\end{array}$ \\
\hline
\end{tabular}


Age 16

Age 17

Age 18

Urban residence

Unemployment rate

Year 2004

Year 2005

Year 2006

Cumulative time in classroom

\begin{tabular}{ll|cc|cc|cl}
0.152 & -0.025 & 0.110 & 0.042 & $-0.408 *$ & -0.037 & -0.030 & $-0.257 *$ \\
$(0.279)$ & $(0.104)$ & $(0.237)$ & $(0.107)$ & $(0.229)$ & $(0.146)$ & $(0.170)$ & $(0.137)$ \\
-0.326 & -0.035 & 0.130 & 0.108 & -0.072 & -0.120 & $-0.446 * *$ & $-0.221 *$ \\
$(0.293)$ & $(0.103)$ & $(0.237)$ & $(0.107)$ & $(0.211)$ & $(0.152)$ & $(0.175)$ & $(0.131)$ \\
$-0.908 * *$ & $-0.269 * *$ & $0.764 * *$ & 0.246 & -0.351 & -0.001 & $-0.592 * * *$ & $-0.429 * * *$ \\
$(0.434)$ & $(0.130)$ & $(0.306)$ & $(0.150)$ & $(0.329)$ & $(0.201)$ & $(0.213)$ & $(0.154)$ \\
0.139 & -0.033 & 0.138 & 0.017 & $-0.586 * * *$ & -0.177 & -0.010 & -0.220 \\
$(0.295)$ & $(0.103)$ & $(0.244)$ & $(0.113)$ & $(0.227)$ & $(0.164)$ & $(0.193)$ & $(0.137)$ \\
0.026 & -0.047 & -0.030 & -0.055 & -0.036 & -0.086 & $0.107 *$ & -0.024 \\
$(0.115)$ & $(0.039)$ & $(0.096)$ & $(0.044)$ & $(0.088)$ & $(0.057)$ & $(0.065)$ & $(0.048)$ \\
-0.195 & -0.100 & $-0.655 * *$ & 0.032 & -0.056 & 0.191 & 0.290 & $0.273 * *$ \\
$(0.299)$ & $(0.106)$ & $(0.280)$ & $(0.117)$ & $(0.263)$ & $(0.154)$ & $(0.186)$ & $(0.126)$ \\
-0.123 & $-0.196 *$ & -0.156 & $0.247 * *$ & 0.130 & 0.046 & $0.555 * * *$ & -0.123 \\
$(0.313)$ & $(0.114)$ & $(0.282)$ & $(0.119)$ & $(0.258)$ & $(0.167)$ & $(0.174)$ & $(0.138)$ \\
-0.385 & -0.021 & $0.438 *$ & $0.201 *$ & $0.516 * *$ & 0.056 & $0.424 * *$ & 0.196 \\
$(0.332)$ & $(0.110)$ & $(0.239)$ & $(0.115)$ & $(0.234)$ & $(0.166)$ & $(0.180)$ & $(0.130)$ \\
& & 0.024 & 0.013 & 0.015 & -0.009 & 0.011 & -0.006 \\
& & $(0.024)$ & $(0.012)$ & $(0.009)$ & $(0.006)$ & $(0.007)$ & $(0.005)$ \\
& & 0.056 & 0.021 & 0.002 & $-0.016 *$ & $0.031 * *$ & -0.011 \\
& & $(0.036)$ & $(0.021)$ & $(0.016)$ & $(0.010)$ & $(0.013)$ & $(0.012)$ \\
& & 0.051 & $0.052 * *$ & 0.005 & -0.008 & 0.007 & $-0.016 * *$ \\
& & $(0.041)$ & $(0.024)$ & $(0.013)$ & $(0.008)$ & $(0.009)$ & $(0.007)$ \\
& & $0.068 * *$ & 0.026 & 0.001 & -0.002 & $0.015 *$ & -0.007 \\
& & $(0.027)$ & $(0.018)$ & $(0.012)$ & $(0.007)$ & $(0.008)$ & $(0.007)$ \\
& & $0.049 * *$ & 0.002 & $-0.024 *$ & -0.006 & 0.001 & -0.006 \\
& $(0.024)$ & $(0.012)$ & $(0.014)$ & $(0.009)$ & $(0.009)$ & $(0.007)$
\end{tabular}

Estimated standard errors appear in parentheses.

* Significant at the 0.10 level, ** significant at the 0.05 level, and *** significant at the 0.01 level. 


\section{Table 3b: Coefficient Estimates for Girls from Supervised and Unsupervised Other Time}

\begin{tabular}{|c|c|c|c|c|c|c|c|c|c|c|}
\hline \multirow{2}{*}{$\begin{array}{r}\text { Initial State: } \\
\text { Ending State: }\end{array}$} & \multicolumn{5}{|c|}{ Supervised Other Time } & \multicolumn{5}{|c|}{ Unsupervised Other Time } \\
\hline & $\begin{array}{l}\text { Class- } \\
\text { room }\end{array}$ & $\begin{array}{c}\text { Other } \\
\text { schooling }\end{array}$ & Work & $\begin{array}{l}\text { Unsuper. } \\
\text { other time }\end{array}$ & $\begin{array}{c}\text { Retiring } \\
\text { sleep }\end{array}$ & $\begin{array}{l}\text { Class- } \\
\text { room }\end{array}$ & $\begin{array}{c}\text { Other } \\
\text { schooling }\end{array}$ & Work & $\begin{array}{l}\text { Supervised } \\
\text { other time }\end{array}$ & $\begin{array}{l}\text { Retiring } \\
\text { sleep }\end{array}$ \\
\hline $\begin{array}{l}\text { Two-parent } \mathrm{HH}, \\
\text { both parents work }\end{array}$ & $\begin{array}{c}0.076 \\
(0.298)\end{array}$ & $\begin{array}{l}-0.235 \\
(0.172)\end{array}$ & $\begin{array}{c}0.116 \\
(0.164)\end{array}$ & $\begin{array}{l}0.045 \\
(0.086)\end{array}$ & $\begin{array}{l}-0.112 \\
(0.217)\end{array}$ & $\begin{array}{l}-0.080 \\
(0.102)\end{array}$ & $\begin{array}{l}-0.020 \\
(0.134)\end{array}$ & $\begin{array}{l}0.303 * * \\
(0.139)\end{array}$ & $\begin{array}{l}-0.082 \\
(0.082)\end{array}$ & $\begin{array}{l}-0.199 * \\
(0.112)\end{array}$ \\
\hline $\begin{array}{l}\text { Two-parent } \mathrm{HH}, \\
\text { father does not wk. }\end{array}$ & $\begin{array}{c}0.355 \\
(0.424)\end{array}$ & $\begin{array}{l}-0.128 \\
(0.313)\end{array}$ & $\begin{array}{l}-0.332 \\
(0.313)\end{array}$ & $\begin{array}{l}-0.005 \\
(0.147)\end{array}$ & $\begin{array}{c}0.260 \\
(0.348)\end{array}$ & $\begin{array}{c}0.003 \\
(0.178)\end{array}$ & $\begin{array}{l}-0.085 \\
(0.231)\end{array}$ & $\begin{array}{l}0.389 * * \\
(0.198)\end{array}$ & $\begin{array}{l}-0.127 \\
(0.135)\end{array}$ & $\begin{array}{c}0.018 \\
(0.188)\end{array}$ \\
\hline Single-parent HH & $\begin{array}{c}0.382 \\
(0.344)\end{array}$ & $\begin{array}{l}-0.800 * * * \\
(0.255)\end{array}$ & $\begin{array}{l}-0.121 \\
(0.202)\end{array}$ & $\begin{array}{l}-0.109 \\
(0.106)\end{array}$ & $\begin{array}{l}-0.321 \\
(0.252)\end{array}$ & $\begin{array}{l}-0.061 \\
(0.121)\end{array}$ & $\begin{array}{l}-0.158 \\
(0.172)\end{array}$ & $\begin{array}{l}0.427 * * * \\
(0.157)\end{array}$ & $\begin{array}{l}-0.308 * * * \\
(0.103)\end{array}$ & $\begin{array}{l}-0.142 \\
(0.133)\end{array}$ \\
\hline $\begin{array}{l}\text { Highest education } \\
\text { obtained by parents }\end{array}$ & $\begin{array}{l}-0.040 \\
(0.043)\end{array}$ & $\begin{array}{l}0.065 * * \\
(0.026)\end{array}$ & $\begin{array}{l}-0.001 \\
(0.023)\end{array}$ & $\begin{array}{l}0.021 * \\
(0.012)\end{array}$ & $\begin{array}{c}-0.089 * * * \\
(0.029)\end{array}$ & $\begin{array}{c}0.006 \\
(0.015)\end{array}$ & $\begin{array}{l}0.079 * * * \\
(0.020)\end{array}$ & $\begin{array}{c}0.003 \\
(0.017)\end{array}$ & $\begin{array}{c}0.017 \\
(0.012)\end{array}$ & $\begin{array}{l}-0.001 \\
(0.016)\end{array}$ \\
\hline Number of & & & & & & & & & & \\
\hline Aged 0-6 & $\begin{array}{l}-0.337 \\
(0.304)\end{array}$ & $\begin{array}{l}-0.159 \\
(0.187)\end{array}$ & $\begin{array}{l}0.252 * * \\
(0.102)\end{array}$ & $\begin{array}{l}-0.096 \\
(0.079)\end{array}$ & $\begin{array}{c}0.073 \\
(0.170)\end{array}$ & $\begin{array}{l}-0.005 \\
(0.090)\end{array}$ & $\begin{array}{l}-0.125 \\
(0.136)\end{array}$ & $\begin{array}{l}0.259 * * * \\
(0.084)\end{array}$ & $\begin{array}{c}0.085 \\
(0.069)\end{array}$ & $\begin{array}{l}-0.089 \\
(0.102)\end{array}$ \\
\hline Aged 7-11 & $\begin{array}{l}0.528 * * * \\
(0.190)\end{array}$ & $\begin{array}{l}-0.320 * * \\
(0.154)\end{array}$ & $\begin{array}{c}0.072 \\
(0.116)\end{array}$ & $\begin{array}{l}-0.041 \\
(0.063)\end{array}$ & $\begin{array}{c}0.026 \\
(0.146)\end{array}$ & $\begin{array}{l}-0.064 \\
(0.077)\end{array}$ & $\begin{array}{c}0.097 \\
(0.097)\end{array}$ & $\begin{array}{l}0.234 * * * \\
(0.078)\end{array}$ & $\begin{array}{c}0.053 \\
(0.058)\end{array}$ & $\begin{array}{l}0.157 * \\
(0.082)\end{array}$ \\
\hline Aged 12-18 & $\begin{array}{c}0.118 \\
(0.160)\end{array}$ & $\begin{array}{l}-0.257 * * \\
(0.102)\end{array}$ & $\begin{array}{l}0.229 * * * \\
(0.080)\end{array}$ & $\begin{array}{l}-0.023 \\
(0.044)\end{array}$ & $\begin{array}{l}-0.067 \\
(0.107)\end{array}$ & $\begin{array}{l}-0.006 \\
(0.049)\end{array}$ & $\begin{array}{l}0.130 * * \\
(0.064)\end{array}$ & $\begin{array}{c}0.081 \\
(0.058)\end{array}$ & $\begin{array}{c}0.005 \\
(0.042)\end{array}$ & $\begin{array}{l}0.136 * * \\
(0.054)\end{array}$ \\
\hline $\begin{array}{l}\text { Number of other } \\
\text { adults }\end{array}$ & $\begin{array}{c}0.205 \\
(0.204)\end{array}$ & $\begin{array}{c}0.039 \\
(0.119)\end{array}$ & $\begin{array}{l}0.216 * * \\
(0.096)\end{array}$ & $\begin{array}{c}0.043 \\
(0.053)\end{array}$ & $\begin{array}{l}-0.140 \\
(0.140)\end{array}$ & $\begin{array}{c}0.009 \\
(0.062)\end{array}$ & $\begin{array}{c}0.015 \\
(0.088)\end{array}$ & $\begin{array}{l}-0.067 \\
(0.069)\end{array}$ & $\begin{array}{c}0.013 \\
(0.051)\end{array}$ & $\begin{array}{c}0.090 \\
(0.061)\end{array}$ \\
\hline Hispanic & $\begin{array}{l}-0.623 \\
(0.395)\end{array}$ & $\begin{array}{l}-0.146 \\
(0.242)\end{array}$ & $\begin{array}{c}0.139 \\
(0.181)\end{array}$ & $\begin{array}{l}0.005 \\
(0.101)\end{array}$ & $\begin{array}{l}-0.510 * \\
(0.273)\end{array}$ & $\begin{array}{c}0.121 \\
(0.123)\end{array}$ & $\begin{array}{l}-0.285 \\
(0.187)\end{array}$ & $\begin{array}{c}0.189 \\
(0.133)\end{array}$ & $\begin{array}{c}0.056 \\
(0.098)\end{array}$ & $\begin{array}{c}0.178 \\
(0.121)\end{array}$ \\
\hline Black & $\begin{array}{c}0.125 \\
(0.397)\end{array}$ & $\begin{array}{l}-0.146 \\
(0.286)\end{array}$ & $\begin{array}{c}0.294 \\
(0.214)\end{array}$ & $\begin{array}{l}0.079 \\
(0.116)\end{array}$ & $\begin{array}{l}-0.125 \\
(0.275)\end{array}$ & $\begin{array}{l}-0.078 \\
(0.124)\end{array}$ & $\begin{array}{l}-0.034 \\
(0.165)\end{array}$ & $\begin{array}{l}-0.289 * \\
(0.153)\end{array}$ & $\begin{array}{l}-0.252 * * \\
(0.109)\end{array}$ & $\begin{array}{c}0.007 \\
(0.133)\end{array}$ \\
\hline Age 16 & $\begin{array}{c}0.153 \\
(0.331)\end{array}$ & $\begin{array}{l}-0.216 \\
(0.185)\end{array}$ & $\begin{array}{c}0.249 \\
(0.177)\end{array}$ & $\begin{array}{c}0.012 \\
(0.088)\end{array}$ & $\begin{array}{c}0.217 \\
(0.220)\end{array}$ & $\begin{array}{l}-0.168 \\
(0.104)\end{array}$ & $\begin{array}{c}0.167 \\
(0.142)\end{array}$ & $\begin{array}{c}0.064 \\
(0.138)\end{array}$ & $\begin{array}{c}0.043 \\
(0.083)\end{array}$ & $\begin{array}{l}-0.235 * * \\
(0.113)\end{array}$ \\
\hline
\end{tabular}




\begin{tabular}{|c|c|c|c|c|c|c|c|c|c|c|}
\hline Age 17 & $\begin{array}{c}0.287 \\
(0.323)\end{array}$ & $\begin{array}{l}-0.277 \\
(0.191)\end{array}$ & $\begin{array}{c}0.168 \\
(0.184)\end{array}$ & $\begin{array}{l}-0.125 \\
(0.092)\end{array}$ & $\begin{array}{l}-0.414 * \\
(0.234)\end{array}$ & $\begin{array}{l}-0.008 \\
(0.104)\end{array}$ & $\begin{array}{c}0.212 \\
(0.144)\end{array}$ & $\begin{array}{l}0.374 * * * \\
(0.132)\end{array}$ & $\begin{array}{l}-0.216 * * \\
(0.089)\end{array}$ & $\begin{array}{l}-0.234 * * \\
(0.113)\end{array}$ \\
\hline Age 18 & $\begin{array}{c}0.653 * \\
(0.382)\end{array}$ & $\begin{array}{l}-0.671 * * \\
(0.298)\end{array}$ & $\begin{array}{c}0.230 \\
(0.226)\end{array}$ & $\begin{array}{l}-0.153 \\
(0.117)\end{array}$ & $\begin{array}{l}-0.335 \\
(0.316)\end{array}$ & $\begin{array}{l}-0.324 * * \\
(0.141)\end{array}$ & $\begin{array}{c}0.068 \\
(0.194)\end{array}$ & $\begin{array}{l}0.783 * * * \\
(0.147)\end{array}$ & $\begin{array}{l}-0.057 \\
(0.113)\end{array}$ & $\begin{array}{l}-0.180 \\
(0.146)\end{array}$ \\
\hline Urban residence & $\begin{array}{c}0.100 \\
(0.294)\end{array}$ & $\begin{array}{c}0.138 \\
(0.198)\end{array}$ & $\begin{array}{c}0.233 \\
(0.186)\end{array}$ & $\begin{array}{c}0.048 \\
(0.089)\end{array}$ & $\begin{array}{c}0.297 \\
(0.243)\end{array}$ & $\begin{array}{l}-0.110 \\
(0.108)\end{array}$ & $\begin{array}{c}0.079 \\
(0.147)\end{array}$ & $\begin{array}{c}0.262 * \\
(0.135)\end{array}$ & $\begin{array}{l}-0.026 \\
(0.086)\end{array}$ & $\begin{array}{c}0.017 \\
(0.112)\end{array}$ \\
\hline Unemployment rate & $\begin{array}{l}-0.026 \\
(0.114)\end{array}$ & $\begin{array}{l}-0.059 \\
(0.076)\end{array}$ & $\begin{array}{c}0.083 \\
(0.067)\end{array}$ & $\begin{array}{l}-0.008 \\
(0.034)\end{array}$ & $\begin{array}{c}0.068 \\
(0.088)\end{array}$ & $\begin{array}{l}-0.075 * \\
(0.040)\end{array}$ & $\begin{array}{c}0.027 \\
(0.053)\end{array}$ & $\begin{array}{l}-0.099 * * \\
(0.048)\end{array}$ & $\begin{array}{l}-0.029 \\
(0.034)\end{array}$ & $\begin{array}{l}-0.085 * * \\
(0.042)\end{array}$ \\
\hline Othe & $\begin{array}{c}0.052 \\
(0.048)\end{array}$ & $\begin{array}{l}0.032 * * * \\
(0.012)\end{array}$ & $\begin{array}{l}-0.011 \\
(0.015)\end{array}$ & $\begin{array}{l}-0.016 * \\
(0.006)\end{array}$ & $\begin{array}{c}0.015 \\
(0.011)\end{array}$ & $\begin{array}{c}0.051 * \\
(0.028)\end{array}$ & $\begin{array}{l}0.044 * * * \\
(0.009)\end{array}$ & $\begin{array}{l}-0.018 \\
(0.012)\end{array}$ & $\begin{array}{l}-0.013 * \\
(0.008)\end{array}$ & $\begin{array}{l}0.021 * * * \\
(0.005)\end{array}$ \\
\hline Work & $\begin{array}{c}0.002 \\
(0.043)\end{array}$ & $\begin{array}{c}0.014 \\
(0.010)\end{array}$ & $\begin{array}{c}0.016 * \\
(0.009)\end{array}$ & $\begin{array}{l}-0.005 \\
(0.004)\end{array}$ & $\begin{array}{c}-0.021 * * * \\
(0.008)\end{array}$ & $\begin{array}{l}0.051 * * \\
(0.022)\end{array}$ & $\begin{array}{l}0.016 * * \\
(0.008)\end{array}$ & $\begin{array}{l}0.021 * * * \\
(0.006)\end{array}$ & $\begin{array}{c}0.008 \\
(0.005)\end{array}$ & $\begin{array}{c}0.000 \\
(0.004)\end{array}$ \\
\hline Sleep & $\begin{array}{l}-0.009 \\
(0.025)\end{array}$ & $\begin{array}{c}0.013 \\
(0.012)\end{array}$ & $\begin{array}{c}0.013 \\
(0.009)\end{array}$ & $\begin{array}{l}-0.003 \\
(0.005)\end{array}$ & $\begin{array}{c}-0.032 * * * \\
(0.011)\end{array}$ & $\begin{array}{c}0.003 \\
(0.012)\end{array}$ & $\begin{array}{c}0.007 \\
(0.009)\end{array}$ & $\begin{array}{l}-0.011 * \\
(0.007)\end{array}$ & $\begin{array}{c}0.002 \\
(0.005)\end{array}$ & $\begin{array}{l}-0.011 * \\
(0.006)\end{array}$ \\
\hline
\end{tabular}

Estimated standard errors appear in parentheses.

* Significant at the 0.10 level, ** significant at the 0.05 level, and *** significant at the 0.01 level. 
Table 4a: Coefficient Estimates for Transitions to Supervised and Unsupervised Other Activities: Boys

\begin{tabular}{|c|c|c|c|c|c|c|c|c|}
\hline \multirow{2}{*}{$\begin{array}{l}\text { Initial State: } \\
\text { Ending State: }\end{array}$} & \multicolumn{2}{|c|}{ Initial Sleep } & \multicolumn{2}{|c|}{ Classroom } & \multicolumn{2}{|c|}{ Other Schooling } & \multicolumn{2}{|c|}{ Work } \\
\hline & $\begin{array}{l}\text { Supervised } \\
\text { other time }\end{array}$ & $\begin{array}{l}\text { Unsuper. } \\
\text { other time }\end{array}$ & $\begin{array}{l}\text { Supervised } \\
\text { other time }\end{array}$ & $\begin{array}{l}\text { Unsuper. } \\
\text { other time }\end{array}$ & $\begin{array}{l}\text { Supervised } \\
\text { other time }\end{array}$ & $\begin{array}{l}\text { Unsuper. } \\
\text { other time }\end{array}$ & $\begin{array}{l}\text { Supervised } \\
\text { other time }\end{array}$ & $\begin{array}{l}\text { Unsuper. } \\
\text { other time }\end{array}$ \\
\hline $\begin{array}{l}\text { Two-parent household, } \\
\text { both parents work }\end{array}$ & $\begin{array}{c}0.025 \\
(0.298)\end{array}$ & $\begin{array}{l}-0.106 \\
(0.108)\end{array}$ & $\begin{array}{l}-0.016 \\
(0.252)\end{array}$ & $\begin{array}{l}-0.115 \\
(0.115)\end{array}$ & $\begin{array}{l}0.793 * * * \\
(0.306)\end{array}$ & $\begin{array}{c}0.141 \\
(0.173)\end{array}$ & $\begin{array}{c}0.316 \\
(0.204)\end{array}$ & $\begin{array}{l}-0.150 \\
(0.142)\end{array}$ \\
\hline $\begin{array}{l}\text { Two-parent household, } \\
\text { father does not work }\end{array}$ & $\begin{array}{c}0.242 \\
(0.427)\end{array}$ & $\begin{array}{c}0.018 \\
(0.156)\end{array}$ & $\begin{array}{c}0.138 \\
(0.360)\end{array}$ & $\begin{array}{l}-0.105 \\
(0.169)\end{array}$ & $\begin{array}{l}0.923 * * \\
(0.375)\end{array}$ & $\begin{array}{c}0.174 \\
(0.256)\end{array}$ & $\begin{array}{c}0.214 \\
(0.301)\end{array}$ & $\begin{array}{c}0.023 \\
(0.202)\end{array}$ \\
\hline Single-parent household & $\begin{array}{l}-0.398 \\
(0.385)\end{array}$ & $\begin{array}{c}0.004 \\
(0.124)\end{array}$ & $\begin{array}{c}0.092 \\
(0.292)\end{array}$ & $\begin{array}{l}-0.110 \\
(0.132)\end{array}$ & $\begin{array}{l}-0.500 \\
(0.445)\end{array}$ & $\begin{array}{c}0.145 \\
(0.217)\end{array}$ & $\begin{array}{l}-0.617 * * \\
(0.284)\end{array}$ & $\begin{array}{l}-0.094 \\
(0.171)\end{array}$ \\
\hline $\begin{array}{l}\text { Highest education obtained } \\
\text { by parents }\end{array}$ & $\begin{array}{l}-0.038 \\
(0.039)\end{array}$ & $\begin{array}{l}-0.018 \\
(0.014)\end{array}$ & $\begin{array}{l}-0.019 \\
(0.031)\end{array}$ & $\begin{array}{c}0.008 \\
(0.015)\end{array}$ & $\begin{array}{l}-0.065 * \\
(0.037)\end{array}$ & $\begin{array}{l}-0.058 * * * \\
(0.022)\end{array}$ & $\begin{array}{c}0.023 \\
(0.028)\end{array}$ & $\begin{array}{l}-0.004 \\
(0.020)\end{array}$ \\
\hline Number of children aged $0-6$ & $\begin{array}{c}0.042 \\
(0.288)\end{array}$ & $\begin{array}{c}0.131 \\
(0.096)\end{array}$ & $\begin{array}{c}0.264 \\
(0.202)\end{array}$ & $\begin{array}{l}-0.010 \\
(0.111)\end{array}$ & $\begin{array}{c}0.343 \\
(0.343)\end{array}$ & $\begin{array}{c}0.192 \\
(0.197)\end{array}$ & $\begin{array}{c}0.207 \\
(0.148)\end{array}$ & $\begin{array}{c}0.138 \\
(0.119)\end{array}$ \\
\hline Number of children aged 7-11 & $\begin{array}{l}-0.064 \\
(0.234)\end{array}$ & $\begin{array}{c}0.085 \\
(0.074)\end{array}$ & $\begin{array}{l}0.359 * * \\
(0.152)\end{array}$ & $\begin{array}{l}-0.032 \\
(0.080)\end{array}$ & $\begin{array}{l}-0.712 * * \\
(0.283)\end{array}$ & $\begin{array}{c}0.131 \\
(0.129)\end{array}$ & $\begin{array}{l}-0.248 * \\
(0.131)\end{array}$ & $\begin{array}{c}0.050 \\
(0.090)\end{array}$ \\
\hline $\begin{array}{l}\text { Number of children aged } \\
12-18\end{array}$ & $\begin{array}{c}0.207 \\
(0.150)\end{array}$ & $\begin{array}{l}-0.015 \\
(0.053)\end{array}$ & $\begin{array}{l}0.397 * * * \\
(0.110)\end{array}$ & $\begin{array}{l}-0.035 \\
(0.055)\end{array}$ & $\begin{array}{l}-0.207 \\
(0.136)\end{array}$ & $\begin{array}{l}-0.032 \\
(0.081)\end{array}$ & $\begin{array}{c}0.016 \\
(0.097)\end{array}$ & $\begin{array}{l}-0.160 * * \\
(0.074)\end{array}$ \\
\hline Number of other adults & $\begin{array}{c}0.211 \\
(0.136)\end{array}$ & $\begin{array}{l}-0.039 \\
(0.054)\end{array}$ & $\begin{array}{c}0.070 \\
(0.120)\end{array}$ & $\begin{array}{l}-0.056 \\
(0.059)\end{array}$ & $\begin{array}{l}-0.095 \\
(0.166)\end{array}$ & $\begin{array}{l}-0.083 \\
(0.105)\end{array}$ & $\begin{array}{l}0.217 * * \\
(0.101)\end{array}$ & $\begin{array}{l}0.159 * * \\
(0.066)\end{array}$ \\
\hline Hispanic & $\begin{array}{c}0.069 \\
(0.311)\end{array}$ & $\begin{array}{l}-0.107 \\
(0.113)\end{array}$ & $\begin{array}{l}-0.052 \\
(0.227)\end{array}$ & $\begin{array}{l}-0.220 * \\
(0.116)\end{array}$ & $\begin{array}{l}-0.802 * * \\
(0.355)\end{array}$ & $\begin{array}{l}-0.115 \\
(0.179)\end{array}$ & $\begin{array}{l}0.442 * \\
(0.250)\end{array}$ & $\begin{array}{l}0.436 * * \\
(0.173)\end{array}$ \\
\hline Black & $\begin{array}{l}-1.126 * * \\
(0.487)\end{array}$ & $\begin{array}{l}-0.211 * \\
(0.120)\end{array}$ & $\begin{array}{l}-0.088 \\
(0.303)\end{array}$ & $\begin{array}{l}-0.241 * \\
(0.136)\end{array}$ & $\begin{array}{l}1.110^{* *} \\
(0.437)\end{array}$ & $\begin{array}{l}0.465 * \\
(0.271)\end{array}$ & $\begin{array}{c}0.021 \\
(0.260)\end{array}$ & $\begin{array}{c}0.125 \\
(0.159)\end{array}$ \\
\hline
\end{tabular}


Age 16

Age 17

Age 18

Urban residence

Unemployment rate

Year 2004

Year 2005

Year 2006

Cumulative time in classroom

Cumulative time in other schooling

Cumulative time in work

Cumulative time in unsupervised other activities

Cumulative time in sleep

\begin{tabular}{ll|ll|ll|ll}
-0.493 & 0.050 & $-0.427 *$ & 0.064 & -0.106 & -0.019 & $-0.474 * *$ & $-0.562 * * *$ \\
$(0.316)$ & $(0.106)$ & $(0.231)$ & $(0.109)$ & $(0.267)$ & $(0.178)$ & $(0.220)$ & $(0.166)$ \\
-0.058 & 0.103 & -0.310 & 0.095 & -0.353 & 0.225 & $-0.582 * * *$ & $-0.385 * *$ \\
$(0.283)$ & $(0.103)$ & $(0.222)$ & $(0.106)$ & $(0.270)$ & $(0.170)$ & $(0.206)$ & $(0.155)$ \\
$-0.703 * *$ & $-0.342 * * *$ & -0.298 & 0.212 & -0.665 & 0.013 & $-0.656 * * *$ & $-0.997 * * *$ \\
$(0.351)$ & $(0.131)$ & $(0.321)$ & $(0.150)$ & $(0.500)$ & $(0.272)$ & $(0.250)$ & $(0.184)$ \\
0.022 & -0.087 & $-0.567 * * *$ & -0.021 & $-0.704 * *$ & -0.040 & $-0.336 *$ & -0.027 \\
$(0.320)$ & $(0.101)$ & $(0.203)$ & $(0.102)$ & $(0.275)$ & $(0.189)$ & $(0.179)$ & $(0.139)$ \\
-0.109 & -0.005 & $0.210 * *$ & -0.001 & 0.167 & -0.039 & 0.066 & $0.136 * *$ \\
$(0.120)$ & $(0.042)$ & $(0.089)$ & $(0.044)$ & $(0.118)$ & $(0.074)$ & $(0.083)$ & $(0.057)$ \\
0.046 & 0.108 & -0.332 & $0.211 *$ & 0.119 & -0.233 & 0.144 & -0.148 \\
$(0.308)$ & $(0.104)$ & $(0.247)$ & $(0.110)$ & $(0.290)$ & $(0.184)$ & $(0.222)$ & $(0.144)$ \\
0.231 & 0.051 & -0.081 & 0.191 & 0.114 & -0.145 & $0.807 * * *$ & 0.046 \\
$(0.321)$ & $(0.113)$ & $(0.269)$ & $(0.121)$ & $(0.328)$ & $(0.202)$ & $(0.218)$ & $(0.159)$ \\
0.319 & 0.159 & $0.527 * *$ & $0.347 * * *$ & 0.233 & $0.395 * *$ & $0.782 * * *$ & 0.120 \\
$(0.333)$ & $(0.115)$ & $(0.261)$ & $(0.129)$ & $(0.356)$ & $(0.200)$ & $(0.238)$ & $(0.164)$ \\
& & $0.044 *$ & $0.024 *$ & 0.000 & 0.006 & -0.002 & $-0.022 * * *$ \\
& & $(0.026)$ & $(0.013)$ & $(0.014)$ & $(0.008)$ & $(0.009)$ & $(0.005)$ \\
& & $0.147 * * *$ & 0.016 & -0.008 & -0.011 & 0.008 & 0.003 \\
& & $(0.040)$ & $(0.024)$ & $(0.016)$ & $(0.010)$ & $(0.017)$ & $(0.012)$ \\
& & $-0.239 *$ & $-0.108 * *$ & -0.016 & 0.003 & -0.013 & $-0.016 * *$ \\
& & $(0.131)$ & $(0.051)$ & $(0.017)$ & $(0.010)$ & $(0.010)$ & $(0.006)$ \\
& & $0.059 * *$ & -0.002 & 0.016 & 0.014 & $0.024 * * *$ & $-0.015 * *$ \\
& & $(0.029)$ & $(0.021)$ & $(0.013)$ & $(0.009)$ & $(0.007)$ & $(0.007)$ \\
& & $0.070 * *$ & $0.024 *$ & 0.000 & 0.014 & 0.009 & $-0.014 * *$ \\
& $(0.030)$ & $(0.014)$ & $(0.018)$ & $(0.011)$ & $(0.011)$ & $(0.007)$
\end{tabular}

Estimated standard errors appear in parentheses.

* Significant at the 0.10 level, ** significant at the 0.05 level, and *** significant at the 0.01 level. 
Table 4b: Coefficient Estimates for Boys from Supervised and Unsupervised Other Time

\begin{tabular}{|c|c|c|c|c|c|c|c|c|c|c|}
\hline \multirow{2}{*}{$\begin{array}{r}\text { Initial State: } \\
\text { Ending State: }\end{array}$} & \multicolumn{5}{|c|}{ Supervised Other Time } & \multicolumn{5}{|c|}{ Unsupervised Other Time } \\
\hline & $\begin{array}{l}\text { Class- } \\
\text { room }\end{array}$ & $\begin{array}{c}\text { Other } \\
\text { schooling }\end{array}$ & Work & $\begin{array}{l}\text { Unsuper. } \\
\text { other time }\end{array}$ & $\begin{array}{l}\text { Retiring } \\
\text { sleep }\end{array}$ & $\begin{array}{l}\text { Class- } \\
\text { room }\end{array}$ & $\begin{array}{c}\text { Other } \\
\text { schooling }\end{array}$ & Work & $\begin{array}{l}\text { Supervised } \\
\text { other time }\end{array}$ & $\begin{array}{l}\text { Retiring } \\
\text { sleep }\end{array}$ \\
\hline $\begin{array}{l}\text { Two-parent } \mathrm{HH}, \\
\text { both parents work }\end{array}$ & $\begin{array}{c}0.225 \\
(0.273)\end{array}$ & $\begin{array}{c}0.143 \\
(0.220)\end{array}$ & $\begin{array}{c}0.031 \\
(0.216)\end{array}$ & $\begin{array}{l}-0.033 \\
(0.091)\end{array}$ & $\begin{array}{c}0.071 \\
(0.260)\end{array}$ & $\begin{array}{l}-0.258 * * \\
(0.120)\end{array}$ & $\begin{array}{l}-0.172 \\
(0.169)\end{array}$ & $\begin{array}{c}0.026 \\
(0.142)\end{array}$ & $\begin{array}{l}-0.078 \\
(0.085)\end{array}$ & $\begin{array}{c}0.016 \\
(0.111)\end{array}$ \\
\hline $\begin{array}{l}\text { Two-parent HH, } \\
\text { father does not wk. }\end{array}$ & $\begin{array}{c}0.018 \\
(0.401)\end{array}$ & $\begin{array}{l}0.135 \\
(0.324)\end{array}$ & $\begin{array}{l}-0.073 \\
(0.308)\end{array}$ & $\begin{array}{l}-0.227 \\
(0.142)\end{array}$ & $\begin{array}{l}0.791 * * \\
(0.353)\end{array}$ & $\begin{array}{l}-0.222 \\
(0.173)\end{array}$ & $\begin{array}{c}0.138 \\
(0.233)\end{array}$ & $\begin{array}{c}0.125 \\
(0.197)\end{array}$ & $\begin{array}{l}-0.231 * \\
(0.133)\end{array}$ & $\begin{array}{l}-0.056 \\
(0.166)\end{array}$ \\
\hline Single-parent HH & $\begin{array}{c}0.066 \\
(0.377)\end{array}$ & $\begin{array}{l}-0.403 \\
(0.316)\end{array}$ & $\begin{array}{l}-0.033 \\
(0.287)\end{array}$ & $\begin{array}{l}0.188 * \\
(0.111)\end{array}$ & $\begin{array}{l}-0.003 \\
(0.310)\end{array}$ & $\begin{array}{l}-0.193 \\
(0.134)\end{array}$ & $\begin{array}{l}-0.357 * \\
(0.212)\end{array}$ & $\begin{array}{l}-0.221 \\
(0.170)\end{array}$ & $\begin{array}{l}-0.277 * * * \\
(0.104)\end{array}$ & $\begin{array}{l}-0.231 * \\
(0.130)\end{array}$ \\
\hline $\begin{array}{l}\text { Highest education } \\
\text { obtained by parents }\end{array}$ & $\begin{array}{l}-0.012 \\
(0.040)\end{array}$ & $\begin{array}{l}0.065 * * \\
(0.031)\end{array}$ & $\begin{array}{c}0.033 \\
(0.031)\end{array}$ & $\begin{array}{c}0.011 \\
(0.013)\end{array}$ & $\begin{array}{c}-0.100 * * * \\
(0.035)\end{array}$ & $\begin{array}{l}0.037 * * \\
(0.015)\end{array}$ & $\begin{array}{l}0.093 * * * \\
(0.023)\end{array}$ & $\begin{array}{l}-0.017 \\
(0.018)\end{array}$ & $\begin{array}{l}-0.009 \\
(0.012)\end{array}$ & $\begin{array}{l}-0.056 * * * \\
(0.016)\end{array}$ \\
\hline Number of children: & & & & & & & & & & \\
\hline $0-6$ & $\begin{array}{l}0.415 * \\
(0.233)\end{array}$ & $\begin{array}{c}0.247 \\
(0.195)\end{array}$ & $\begin{array}{l}0.261 * \\
(0.152)\end{array}$ & $\begin{array}{c}0.007 \\
(0.083)\end{array}$ & $\begin{array}{l}-0.200 \\
(0.293)\end{array}$ & $\begin{array}{l}-0.009 \\
(0.111)\end{array}$ & $\begin{array}{l}-0.041 \\
(0.174)\end{array}$ & $\begin{array}{l}-0.050 \\
(0.118)\end{array}$ & $\begin{array}{l}-0.022 \\
(0.080)\end{array}$ & $\begin{array}{l}-0.020 \\
(0.106)\end{array}$ \\
\hline Aged 7-11 & $\begin{array}{c}0.137 \\
(0.190)\end{array}$ & $\begin{array}{l}-0.101 \\
(0.159)\end{array}$ & $\begin{array}{c}0.033 \\
(0.152)\end{array}$ & $\begin{array}{l}0.173 * * * \\
(0.059)\end{array}$ & $\begin{array}{l}-0.296 \\
(0.191)\end{array}$ & $\begin{array}{c}0.024 \\
(0.084)\end{array}$ & $\begin{array}{l}-0.212 \\
(0.134)\end{array}$ & $\begin{array}{l}0.391 * * * \\
(0.081)\end{array}$ & $\begin{array}{c}0.063 \\
(0.059)\end{array}$ & $\begin{array}{l}-0.049 \\
(0.076)\end{array}$ \\
\hline Aged 12 & $\begin{array}{l}-0.276 * * \\
(0.126)\end{array}$ & $\begin{array}{l}-0.077 \\
(0.116)\end{array}$ & $\begin{array}{l}0.219 * * \\
(0.111)\end{array}$ & $\begin{array}{l}-0.014 \\
(0.047)\end{array}$ & $\begin{array}{l}-0.081 \\
(0.127)\end{array}$ & $\begin{array}{c}0.018 \\
(0.059)\end{array}$ & $\begin{array}{c}0.103 \\
(0.085)\end{array}$ & $\begin{array}{c}0.034 \\
(0.069)\end{array}$ & $\begin{array}{l}0.132 * * * \\
(0.042)\end{array}$ & $\begin{array}{l}0.109 * * \\
(0.055)\end{array}$ \\
\hline $\begin{array}{l}\text { Number of other } \\
\text { adults }\end{array}$ & $\begin{array}{l}-0.326 * \\
(0.188)\end{array}$ & $\begin{array}{c}0.095 \\
(0.113)\end{array}$ & $\begin{array}{l}0.351 * * * \\
(0.100)\end{array}$ & $\begin{array}{l}-0.065 \\
(0.048)\end{array}$ & $\begin{array}{l}-0.056 \\
(0.109)\end{array}$ & $\begin{array}{l}-0.014 \\
(0.056)\end{array}$ & $\begin{array}{l}-0.211 * * \\
(0.104)\end{array}$ & $\begin{array}{c}0.089 \\
(0.063)\end{array}$ & $\begin{array}{l}0.079 * \\
(0.043)\end{array}$ & $\begin{array}{c}0.053 \\
(0.059)\end{array}$ \\
\hline Hispanic & $\begin{array}{l}-0.154 \\
(0.310)\end{array}$ & $\begin{array}{l}0.457 * * \\
(0.232)\end{array}$ & $\begin{array}{l}-0.343 \\
(0.279)\end{array}$ & $\begin{array}{c}0.033 \\
(0.102)\end{array}$ & $\begin{array}{l}-0.216 \\
(0.280)\end{array}$ & $\begin{array}{l}-0.185 \\
(0.124)\end{array}$ & $\begin{array}{c}0.120 \\
(0.174)\end{array}$ & $\begin{array}{l}-0.382 * * \\
(0.160)\end{array}$ & $\begin{array}{l}-0.188 * * \\
(0.091)\end{array}$ & $\begin{array}{c}0.015 \\
(0.120)\end{array}$ \\
\hline Black & $\begin{array}{l}-0.025 \\
(0.351)\end{array}$ & $\begin{array}{l}-0.221 \\
(0.330)\end{array}$ & $\begin{array}{l}-1.462 * * * \\
(0.491)\end{array}$ & $\begin{array}{l}-0.002 \\
(0.118)\end{array}$ & $\begin{array}{c}0.068 \\
(0.319)\end{array}$ & $\begin{array}{l}-0.138 \\
(0.143)\end{array}$ & $\begin{array}{l}-1.029 * * * \\
(0.302)\end{array}$ & $\begin{array}{c}0.074 \\
(0.146)\end{array}$ & $\begin{array}{l}-0.503^{* * * *} \\
(0.115)\end{array}$ & $\begin{array}{l}-0.113 \\
(0.126)\end{array}$ \\
\hline Age 16 & $\begin{array}{l}-0.511 * \\
(0.281)\end{array}$ & $\begin{array}{l}-0.151 \\
(0.225)\end{array}$ & $\begin{array}{l}-0.148 \\
(0.231)\end{array}$ & $\begin{array}{c}0.019 \\
(0.091)\end{array}$ & $\begin{array}{c}-0.682 * * * \\
(0.238)\end{array}$ & $\begin{array}{c}0.064 \\
(0.113)\end{array}$ & $\begin{array}{c}0.163 \\
(0.180)\end{array}$ & $\begin{array}{l}0.426^{* * *} \\
(0.153)\end{array}$ & $\begin{array}{c}0.134 \\
(0.085)\end{array}$ & $\begin{array}{l}-0.055 \\
(0.114)\end{array}$ \\
\hline
\end{tabular}




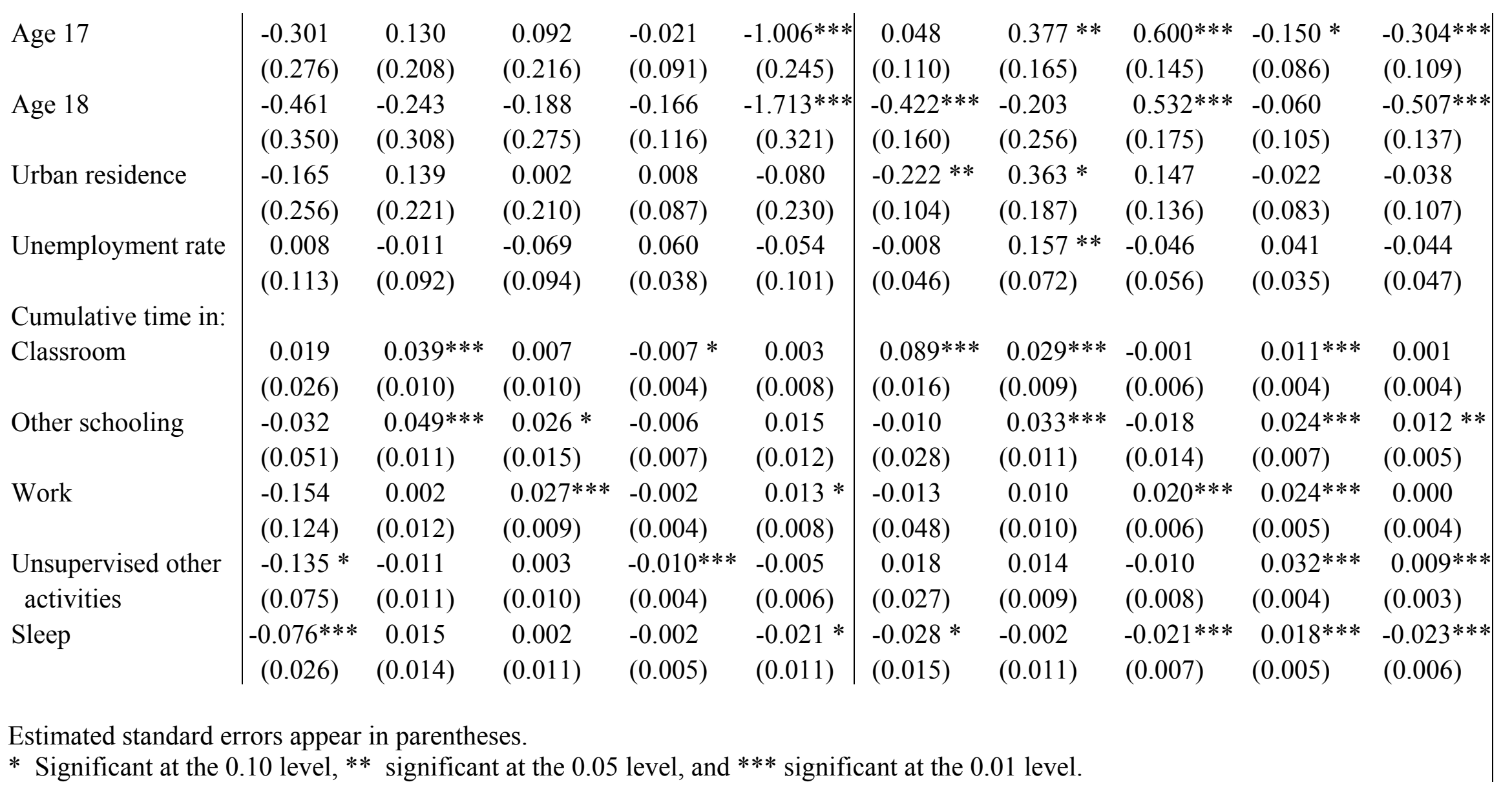


Table 5a: Simulation results for girls

\begin{tabular}{|c|c|c|c|c|c|c|c|c|c|c|}
\hline & \multicolumn{2}{|c|}{ Classroom } & \multicolumn{2}{|c|}{ Other schooling } & \multicolumn{2}{|c|}{ Work } & \multirow{2}{*}{\multicolumn{2}{|c|}{$\begin{array}{c}\text { Supervised } \\
\text { other activities }\end{array}$}} & \multirow{3}{*}{$\begin{array}{c}\text { Unsupervised } \\
\text { other activities } \\
\text { minutes }\end{array}$} & \multirow[t]{2}{*}{ Sleep } \\
\hline & \multirow[b]{2}{*}{ minutes } & \multirow[b]{2}{*}{ incidence } & \multirow[b]{2}{*}{ minutes } & \multirow[b]{2}{*}{ incidence } & \multirow[b]{2}{*}{ minutes } & \multirow[b]{2}{*}{ incidence } & & & & \\
\hline & & & & & & & minutes & incidence & & minutes \\
\hline & $(\%$ change $)$ & $(\%$ change $)$ & $(\%$ change $)$ & $(\%$ change $)$ & $(\%$ change $)$ & $(\%$ change $)$ & $(\%$ change $)$ & $(\%$ change $)$ & (\% change) & (\% change $)$ \\
\hline Baseline & 228.9 & $61.4 \%$ & 65.4 & $53.1 \%$ & 85.4 & $61.3 \%$ & 168.9 & $85.3 \%$ & 348.7 & 542.8 \\
\hline Two-parent HH, & 225.8 & $61.8 \%$ & 69.0 & $55.9 \%$ & 70.5 & $57.3 \%$ & 185.2 & $88.7 \%$ & 337.5 & 552.0 \\
\hline \multicolumn{11}{|l|}{ only father works (a) } \\
\hline Two-parent HH, & 230.7 & $61.5 \%$ & 69.7 & $54.4 \%$ & 90.1 & $62.7 \%$ & 163.5 & $85.6 \%$ & 348.9 & 537.2 \\
\hline both parents work (a) & $(2.1 \%)$ & $(-0.5 \%)$ & $(1.0 \%)$ & $(-2.7 \%)$ & $(23.0 \%)$ & $(8.7 \%)$ & $(-12.8 \%)$ & $(-3.7 \%)$ & $(3.2 \%)$ & $(-2.7 \%)$ \\
\hline Two-parent HH, & 234.6 & $63.2 \%$ & 67.5 & $53.3 \%$ & 88.4 & $60.7 \%$ & 152.4 & $82.3 \%$ & 344.7 & 552.4 \\
\hline father does not wk (a) & $(3.9 \%)$ & $(2.3 \%)$ & $(-2.4 \%)$ & $(-4.7 \%)$ & $(21.0 \%)$ & $(5.5 \%)$ & $(-19.4 \%)$ & $(-7.6 \%)$ & $(2.0 \%)$ & $(0.1 \%)$ \\
\hline \multirow[t]{2}{*}{ Single parent $\mathrm{HH}$ (a) } & 225.5 & $60.6 \%$ & 52.3 & $46.9 \%$ & 87.9 & $63.1 \%$ & 175.2 & $83.6 \%$ & 359.3 & 539.9 \\
\hline & $(-0.1 \%)$ & $(-1.9 \%)$ & $(-25.6 \%)$ & $(-16.9 \%)$ & $(20.4 \%)$ & $(9.5 \%)$ & $(-5.9 \%)$ & $(-6.0 \%)$ & $(6.2 \%)$ & $(-2.2 \%)$ \\
\hline Highest education & 228.7 & $61.3 \%$ & 69.8 & $54.6 \%$ & 84.6 & $61.2 \%$ & 167.3 & $85.1 \%$ & 347.1 & 542.5 \\
\hline obtained by parents & $(-0.1 \%)$ & $(-0.2 \%)$ & $(6.7 \%)$ & $(2.9 \%)$ & $(-0.9 \%)$ & $(-0.1 \%)$ & $(-1.0 \%)$ & $(-0.2 \%)$ & $(-0.4 \%)$ & $(-0.1 \%)$ \\
\hline \multicolumn{11}{|l|}{ Number of children: } \\
\hline \multirow[t]{2}{*}{ Aged 0-6 } & 220.8 & $59.1 \%$ & 60.1 & $49.4 \%$ & 95.2 & $67.9 \%$ & 184.7 & $86.8 \%$ & 334.0 & 545.1 \\
\hline & $(-3.5 \%)$ & $(-3.8 \%)$ & $(-8.1 \%)$ & $(-7.0 \%)$ & $(11.5 \%)$ & $(10.8 \%)$ & $(9.4 \%)$ & $(1.7 \%)$ & $(-4.2 \%)$ & $(0.4 \%)$ \\
\hline \multirow[t]{2}{*}{ Aged 7-11 } & 231.6 & $62.5 \%$ & 65.4 & $51.6 \%$ & 88.9 & $66.1 \%$ & 171.4 & $85.2 \%$ & 333.5 & 549.3 \\
\hline & $(1.2 \%)$ & $(1.8 \%)$ & $(-0.0 \%)$ & $(-2.8 \%)$ & $(4.1 \%)$ & $(7.8 \%)$ & $(1.5 \%)$ & $(-0.1 \%)$ & $(-4.4 \%)$ & $(1.2 \%)$ \\
\hline \multirow[t]{2}{*}{ Aged 12-18 } & 232.9 & $61.7 \%$ & 65.3 & $53.3 \%$ & 91.0 & $64.3 \%$ & 165.2 & $84.8 \%$ & 338.1 & 547.6 \\
\hline & $(1.7 \%)$ & $(0.4 \%)$ & $(-0.2 \%)$ & $(0.4 \%)$ & $(6.5 \%)$ & $(5.0 \%)$ & $(-2.2 \%)$ & $(-0.6 \%)$ & $(-3.0 \%)$ & $(0.9 \%)$ \\
\hline \multirow[t]{2}{*}{ Number of other adults } & 229.0 & $62.5 \%$ & 66.2 & $53.8 \%$ & 90.1 & $62.1 \%$ & 157.7 & $84.9 \%$ & 354.8 & 542.2 \\
\hline & $(0.1 \%)$ & $(1.8 \%)$ & $(1.1 \%)$ & $(1.4 \%)$ & $(5.5 \%)$ & $(1.3 \%)$ & $(-6.6 \%)$ & $(-0.4 \%)$ & $(1.8 \%)$ & $(-0.1 \%)$ \\
\hline White (b) & 226.3 & $61.9 \%$ & 65.0 & $53.8 \%$ & 87.6 & $61.6 \%$ & 176.2 & $86.9 \%$ & 344.4 & 540.6 \\
\hline \multirow[t]{2}{*}{ Hispanic (b) } & 237.4 & $59.6 \%$ & 64.4 & $48.2 \%$ & 85.8 & $64.2 \%$ & 171.4 & $84.3 \%$ & 329.4 & 551.6 \\
\hline & $(4.9 \%)$ & $(-3.8 \%)$ & $(-0.9 \%)$ & $(-10.6 \%)$ & $(-2.0 \%)$ & $(4.3 \%)$ & $(-2.9 \%)$ & $(-3.0 \%)$ & $(-4.3 \%)$ & $(2.0 \%)$ \\
\hline \multirow[t]{2}{*}{ Black (b) } & 236.9 & $62.4 \%$ & 69.8 & $53.7 \%$ & 76.6 & $58.1 \%$ & 130.6 & $79.7 \%$ & 391.9 & 534.2 \\
\hline & $(4.6 \%)$ & $(0.8 \%)$ & $(7.3 \%)$ & $(-0.1 \%)$ & $(-12.8 \%)$ & $(-5.7 \%)$ & $(-27.0 \%)$ & $(-8.3 \%)$ & $(13.6 \%)$ & $(-1.2 \%)$ \\
\hline \multirow[t]{2}{*}{ Unemployment rate } & 222.4 & $60.1 \%$ & 66.7 & $52.2 \%$ & 82.0 & $60.6 \%$ & 169.8 & $85.8 \%$ & 356.9 & 542.2 \\
\hline & $(-2.8 \%)$ & $(-2.2 \%)$ & $(1.9 \%)$ & $(-1.6 \%)$ & $(-4.0 \%)$ & $(-1.1 \%)$ & $(0.5 \%)$ & $(0.6 \%)$ & $(2.4 \%)$ & $(-0.1 \%)$ \\
\hline
\end{tabular}

The baseline results are derived from a simulation conducted using the characteristics actually observed in the data.

(a) Changes in household type are identified relative to two-parent households in which only the father works.

(b) Changes in race/ethnicity are identified relative to white persons. 
Table 5b: Simulation results for boys

\begin{tabular}{|c|c|c|c|c|c|c|c|c|c|c|}
\hline & \multicolumn{2}{|c|}{ Classroom } & \multicolumn{2}{|c|}{ Other schooling } & \multicolumn{2}{|c|}{ Work } & \multirow{2}{*}{\multicolumn{2}{|c|}{$\begin{array}{c}\text { Supervised } \\
\text { other activities }\end{array}$}} & \multirow{3}{*}{$\begin{array}{c}\text { Unsupervised } \\
\text { other activities } \\
\text { minutes }\end{array}$} & \multirow[t]{2}{*}{ Sleep } \\
\hline & \multirow[b]{2}{*}{ minutes } & \multirow[b]{2}{*}{ incidence } & \multirow[b]{2}{*}{ minutes } & \multirow[b]{2}{*}{ incidence } & \multirow[b]{2}{*}{ minutes } & \multirow[b]{2}{*}{ incidence } & & & & \\
\hline & & & & & & & minutes & incidence & & minutes \\
\hline & $(\%$ change $)$ & $(\%$ change $)$ & ( $\%$ change $)$ & $(\%$ change $)$ & $(\%$ change $)$ & (\% change $)$ & (\% change $)$ & $(\%$ change $)$ & (\% change $)$ & (\% change $)$ \\
\hline Baseline & 238.4 & $60.9 \%$ & 46.1 & $40.5 \%$ & 78.9 & $51.0 \%$ & 155.8 & $81.0 \%$ & 379.3 & 541.5 \\
\hline Two-parent HH, & 247.7 & $62.3 \%$ & 54.4 & $43.5 \%$ & 78.4 & $51.8 \%$ & 163.2 & $82.1 \%$ & 356.2 & 540.2 \\
\hline \multicolumn{11}{|l|}{ only father works (a) } \\
\hline Two-parent HH, & 233.1 & $60.1 \%$ & 44.6 & $41.3 \%$ & 77.4 & $51.9 \%$ & 167.9 & $83.3 \%$ & 368.8 & 548.3 \\
\hline both parents work (a) & $(-6.1 \%)$ & $(-3.8 \%)$ & $(-21.2 \%)$ & $(-5.6 \%)$ & $(-1.3 \%)$ & $(0.2 \%)$ & $(3.0 \%)$ & $(1.5 \%)$ & $(3.3 \%)$ & $(1.5 \%)$ \\
\hline Two-parent HH, & 242.2 & $61.6 \%$ & 51.2 & $45.2 \%$ & 77.0 & $53.3 \%$ & 167.3 & $81.0 \%$ & 356.1 & 546.1 \\
\hline father does not wk (a) & $(-2.3 \%)$ & $(-1.3 \%)$ & $(-6.8 \%)$ & $(4.2 \%)$ & $(-1.8 \%)$ & $(2.9 \%)$ & $(2.7 \%)$ & $(-1.3 \%)$ & $(-0.0 \%)$ & $(1.1 \%)$ \\
\hline \multirow[t]{2}{*}{ Single parent $\mathrm{HH}$ (a) } & 243.9 & $61.5 \%$ & 41.7 & $36.2 \%$ & 80.3 & $47.6 \%$ & 119.6 & $75.4 \%$ & 429.1 & 525.4 \\
\hline & $(-1.6 \%)$ & $(-1.4 \%)$ & $(-27.4 \%)$ & $(-18.1 \%)$ & $(2.4 \%)$ & $(-8.1 \%)$ & $(-28.0 \%)$ & $(-8.3 \%)$ & $(19.2 \%)$ & $(-2.7 \%)$ \\
\hline Highest education & 238.1 & $60.7 \%$ & 50.8 & $42.7 \%$ & 78.1 & $50.5 \%$ & 154.3 & $80.7 \%$ & 380.5 & 538.3 \\
\hline obtained by parents & $(-0.1 \%)$ & $(-0.3 \%)$ & $(10.1 \%)$ & $(5.3 \%)$ & $(-1.0 \%)$ & $(-1.1 \%)$ & $(-1.0 \%)$ & $(-0.3 \%)$ & $(0.3 \%)$ & $(-0.6 \%)$ \\
\hline \multicolumn{11}{|l|}{ Number of children: } \\
\hline \multirow[t]{2}{*}{ Aged 0-6 } & 252.4 & $63.4 \%$ & 46.8 & $43.4 \%$ & 74.1 & $52.7 \%$ & 150.2 & $81.8 \%$ & 390.1 & 526.4 \\
\hline & $(5.9 \%)$ & $(4.2 \%)$ & $(1.6 \%)$ & $(7.1 \%)$ & $(-6.1 \%)$ & $(3.2 \%)$ & $(-3.6 \%)$ & $(1.0 \%)$ & $(2.8 \%)$ & $(-2.8 \%)$ \\
\hline \multirow[t]{2}{*}{ Aged 7-11 } & 245.1 & $62.4 \%$ & 43.0 & $38.6 \%$ & 105.0 & $59.6 \%$ & 142.4 & $81.1 \%$ & 376.7 & 527.9 \\
\hline & $(2.8 \%)$ & $(2.5 \%)$ & $(-6.7 \%)$ & $(-4.9 \%)$ & $(33.1 \%)$ & $(16.9 \%)$ & $(-8.7 \%)$ & $(0.2 \%)$ & $(-0.7 \%)$ & $(-2.5 \%)$ \\
\hline \multirow[t]{2}{*}{ Aged 12-18 } & 232.0 & $60.5 \%$ & 49.7 & $41.8 \%$ & 90.4 & $53.6 \%$ & 174.1 & $84.5 \%$ & 348.4 & 545.5 \\
\hline & $(-2.7 \%)$ & $(-0.6 \%)$ & $(7.7 \%)$ & $(3.2 \%)$ & $(14.6 \%)$ & $(5.1 \%)$ & $(11.7 \%)$ & $(4.3 \%)$ & $(-8.2 \%)$ & $(0.8 \%)$ \\
\hline \multirow[t]{2}{*}{ Number of other adults } & 232.4 & $59.9 \%$ & 45.1 & $38.8 \%$ & 80.3 & $55.5 \%$ & 171.4 & $83.3 \%$ & 366.4 & 544.4 \\
\hline & $(-2.5 \%)$ & $(-1.6 \%)$ & $(-2.3 \%)$ & $(-4.2 \%)$ & $(1.8 \%)$ & $(8.7 \%)$ & $(10.0 \%)$ & $(2.8 \%)$ & $(-3.4 \%)$ & $(0.6 \%)$ \\
\hline White (b) & 242.7 & $61.9 \%$ & 48.0 & $41.7 \%$ & 87.8 & $53.1 \%$ & 160.5 & $83.0 \%$ & 362.1 & 538.8 \\
\hline \multirow[t]{2}{*}{ Hispanic (b) } & 232.2 & $59.4 \%$ & 60.6 & $45.7 \%$ & 49.1 & $44.0 \%$ & 150.4 & $80.3 \%$ & 437.2 & 548.0 \\
\hline & $(-4.4 \%)$ & $(-4.1 \%)$ & $(27.3 \%)$ & $(10.0 \%)$ & $(-49.1 \%)$ & $(-17.7 \%)$ & $(-6.5 \%)$ & $(-3.4 \%)$ & $(19.8 \%)$ & $(1.7 \%)$ \\
\hline \multirow[t]{2}{*}{ Black (b) } & 227.1 & $57.8 \%$ & 22.4 & $28.2 \%$ & 72.0 & $48.8 \%$ & 133.5 & $72.6 \%$ & 399.8 & 547.8 \\
\hline & $(-6.5 \%)$ & $(-6.9 \%)$ & $(-55.6 \%)$ & $(-33.3 \%)$ & $(-20.0 \%)$ & $(-8.3 \%)$ & $(-17.4 \%)$ & $(-12.8 \%)$ & $(9.9 \%)$ & $(1.7 \%)$ \\
\hline \multirow[t]{2}{*}{ Unemployment rate } & 235.9 & $60.8 \%$ & 49.8 & $42.9 \%$ & 71.2 & $49.8 \%$ & 159.3 & $82.6 \%$ & 383.2 & 540.6 \\
\hline & $(-1.1 \%)$ & $(-0.1 \%)$ & $(8.1 \%)$ & $(6.0 \%)$ & $(-9.8 \%)$ & $(-2.4 \%)$ & $(2.2 \%)$ & $(2.1 \%)$ & $(1.0 \%)$ & $(-0.2 \%)$ \\
\hline
\end{tabular}

The baseline results are derived from a simulation conducted using the characteristics actually observed in the data.

(a) Changes in household type are identified relative to two-parent households in which only the father works.

(b) Changes in race/ethnicity are identified relative to white persons. 